\title{
Os escritos de Giovanni Angelo Brunelli, astrônomo da Comissão Demarcadora de Limites portuguesa (1753-1761), sobre a Amazônia brasileira \\ The writings of Giovanni Angelo Brunelli, astronomer of the Portuguese Boundaries Demarcation Committee (1753-1761), about the Brazilian Amazonia
}

\author{
Nelson Papavero' \\ Nelson Sanjad" \\ Abner Chiquierill \\ William Leslie Overal ${ }^{\mathrm{N}}$ \\ Riccardo Mugnaiv
}

Resumo: $\bigcirc$ texto apresenta breve introdução à vida e à obra de Giovanni Angelo Brunelli (1722-1804), astrônomo bolonhês que participou da primeira Comissão Demarcadora de Limites entre as possessões de Portugal e Espanha na América do Sul, de 1753 a 1761, a serviço da Coroa lusitana. Em seguida, são publicados os três trabalhos de Brunelli sobre a Amazônia brasileira, tendo como temas a pororoca (1767), a mandioca (1767) e o rio Amazonas (1791); e dois outros documentos relacionadas à comissão, um ofício no qual Brunelli reclama a coordenação dos trabalhos de cartografia (1752) e um rascunho do diário de viagem do astrônomo até o rio Negro (1754). Todos esses documentos foram traduzidos ao português, pela primeira vez, do latim e do italiano.

Palavras-chave: Tratado de Madri. Comissão Demarcadora de Limites. Giovanni Angelo Brunelli. Pororoca. Mandioca. Rio Amazonas.

\begin{abstract}
The text presents an introduction to the life and works of Giovanni Angelo Brunelli (1722-1804), a Bolognese astronomer that participated in the first Boundaries Demarcation Committee (1753 to 1761) between Portugal and Spain's South American possessions, serving the Portuguese Crown. The three works of Brunelli about the Brazilian Amazonia are published, whose themes are the 'pororoca' (1767), the manioc (1767), and the Amazon River (1791). Two others documents related to the demarcation committee are also published: Brunelli's letter complaining about the coordination of cartographic works (1752) and the draft of the astronomer's travel diary to the Negro River (1754). All of these documents were translated to Portuguese, for the first time, from the Latin and Italian.
\end{abstract}

Keywords: Treaty of Madrid. Boundaries Demarcation Committee. Giovanni Angelo Brunelli. Pororoca. Manioc. Amazon River.

Universidade de São Paulo. Museu de Zoologia. São Paulo, São Paulo, Brasil (nelsonpapavero@gmail.com).

" Museu Paraense Emílio Goeldi/MCT. Coordenação de Comunicação e Extensão. Belém, Pará, Brasil (nsanjad@museu-goeldi.br).

III Universidade Federal Rural do Rio de Janeiro. Seropédica, Rio de Janeiro, Brasil (chiquier@terra.com.br).

v Museu Paraense Emílio Goeldi/MCT. Coordenação de Zoologia. Belém, Pará, Brasil (overal@museu-goeldi.br).

$\checkmark$ Fundação Oswaldo Cruz. Instituto Oswaldo Cruz. Rio de Janeiro, Rio de Janeiro, Brasil (mugnai@ioc.fiocruz.br).

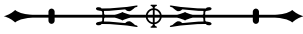




\section{INTRODUÇÃO}

Pouco se sabe sobre a vida de Giovanni Angelo Brunelli (1722-1804), a não ser por algumas informações esparsas encontradas em cartas por ele recebidas de alguns amigos, hoje depositadas na Coleção Brunelli, da Divisão de Manuscritos da Biblioteca Nacional do Rio de Janeiro (BNRJ) (Robustelli, 1996), e em documentos manuscritos sobre a Capitania do Grão-Pará existentes no Arquivo Histórico Ultramarino (AHU), de Lisboa (Projeto Resgate..., 2002). De suas atividades profissionais, são conhecidos principalmente os serviços prestados à Coroa portuguesa. O nome de Brunelli aparece vinculado à primeira Comissão Demarcadora de Limites (1753), organizada em decorrência do Tratado de Madri (1750); ao Real Colégio dos Nobres (1761), criado pelo Marquês de Pombal em Lisboa; à Academia Real das Ciências de Lisboa (1779); e à tradução para o português de tratados de matemática e geometria (Ribeiro, 1876; Reis, 1948, 1959; Mendonça, 1963; Domingues, 1991; Munteal Filho, 1998; Papavero et al., 2002a; Mendonça, 2003; Sanjad e Pataca, 2007; Moura, 2008). A literatura faz pouca referência à obra de Brunelli sobre a Amazônia brasileira, se a comparamos com outros escritos de cariz científico produzidos no século XVIII, como os de Charles-Marie de La Condamine (1701-1774), João Daniel (1722-1776), Antonio Giuseppe Landi (1713-1791) e Alexandre Rodrigues Ferreira (1756-1815).

Brunelli publicou três trabalhos sobre a região amazônica. O primeiro, de 1767, foi intitulado "De Pororoca" ("Sobre a Pororoca") e apareceu em forma de epístola, em latim, na revista da Academia de Ciências do Instituto de Bolonha (Brunelli, 1767a). Foi endereçado a Eustachio Zanotti (1709-1782), à época diretor do Observatório Astronômico'. Esse texto de Brunelli pode ser considerado uma das primeiras tentativas de explicar cientificamente o "grandioso" e "admirável" fenômeno físico que ocorre em toda a região da foz do Amazonas e do Tocantins. Pondo à prova sua própria capacidade de observação e interpretação, como defende ser a obrigação dos que "apreciam dedicar-se à contemplação da natureza" (Brunelli, 1767a, p. 249), Brunelli arrisca uma explicação que hoje nos parece fantasiosa, mas que à época era plausível por não se conhecer, ainda, a complexa hidrologia e hidrografia da região: para ele, a pororoca do rio Guamá, e certamente a de outros rios amazônicos, teria origem em canais subterrâneos que ligariam o fundo do oceano ao leito, por onde fluiria e refluiria a água, em grandes quantidades e com imensa força provocada pela lei da gravidade e pela atração da Lua e do Sol. Desacreditando das explicações que ouvira no local, muitas das quais consideradas obscuras e ridículas - infelizmente, Brunelli não as relata -, o autor oferece raciocínio alternativo à crença, já vigente na época, como ele próprio registra, de que a causa das gigantes ondas residiria na força do mar, que impeliria as águas a montante com maior ímpeto do que a correnteza dos rios seria capaz de reter (Anexo 3).

O segundo trabalho, também de 1767, apareceu na mesma revista, em latim e na forma epistolar, desta vez endereçado ao bolonhês Ferdinando Bassi (1710-1774), diretor do Horto Médico de Plantas Exóticas² (Brunelli,

\footnotetext{
Aos 20 anos, o bolonhês Zanotti era assistente da Academia de Ciências, sendo discípulo de Eustachio Manfredi (ver nota 15). Após a morte de seu mestre, em 1738, sucedeu-o na direção do Observatório Astronômico e continuou suas atividades, publicando três volumes das "Efemérides Bolonhesas" (1751-1764) em colaboração com os assistentes Petronio Mateucci e Gabrielle Brunelli. Com os novos instrumentos recebidos em 1741, efetuou numerosas observações sobre o Sol, a Lua, planetas e cometas, publicadas nas atas de academias italianas e estrangeiras. Foi também um grande engenheiro hidráulico. Em 1778, tornou-se secretário do Istituto delle Scienze di Bologna. Foi membro das academias de Berlim e Londres. Sua biografia foi publicada por Palcani-Caccianemici (1784) e, mais modernamente, por d'Arturo e Tempesti (1960, p. 364).

2 Ferdinando Bassi foi assistente do botânico Giuseppe Monti, da Academia das Ciências de Bolonha, encarregado de tratar de intercâmbios de material com outros naturalistas italianos e europeus, dando assim início à sua carreira científica, que se desenvolveu quase inteiramente entre o Jardim Botânico e a Academia de Ciência daquela cidade. Em 1773, Bassi foi nomeado 'Prefetto' do Orto Medico delle Piante Esotiche, que ampliou e enriqueceu, incrementando os intercâmbios de material com seus correspondentes e entrando em contato com outros botânicos, tanto italianos como estrangeiros, dos quais recebeu plantas e sementes, exsicatas e literatura. A colaboração de Bassi com a Academia de Ciência seguiu fundamentalmente duas diretrizes: uma quase que exclusivamente botânica, prevalentemente sistemática, dirigida seja à descrição de novas espécies seja ao aprofundamento e à detalhada descrição de plantas já conhecidas, mas inadequadamente tratadas pelos botânicos precedentes. Nesses anos, Bassi entrou em contato com Linnaeus, e toda vez que achava ter feito alguma descoberta interessante, escrevia ao naturalista sueco pedindo-lhe conselho (Cristofolini e Biagi, 2007).
}

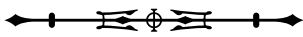


1767b). O texto, com o título "De Mannioca" ("Sobre a Mandioca"), é uma boa descrição do conjunto de saberes, técnicas e objetos vinculados à planta. Brunelli inicia relatando as formas de cultivo; os instrumentos utilizados na preparação dos produtos derivados das raízes, como o ralador, o pilão, o tipiti e a panela; os alimentos e a forma de preparação e de ingestão. São mencionados a "farinha cica", a farinha d'água, a farinha de carimã, a tapioca, o "elegantíssimo" tacacá, o beiju, o cauim, a maniçoba e o tucupi. Também são referidas, infelizmente de passagem, as adaptações que os "apressados" europeus fizeram de alguns desses alimentos e da forma de fabricá-los. Isso demonstra como incorporaram a dieta indígena, por várias vezes elogiada por Brunelli, que se confessa apreciador de muitas iguarias e "um homem já tão perto do americano" (Anexo 4).

O terceiro e maior texto, publicado em 1791, foi intitulado "De flumine Amazonum" ("Sobre o rio Amazonas"). Na forma de discurso, em latim, faz uma descrição mais ou menos detalhada do curso d'água, das nascentes nos Andes peruanos à foz, destacando como um dos principais afluentes o rio Negro, que Brunelli conhecera pessoalmente (Brunelli, 1791). Ao longo do texto, são descritos o encontro das águas deste último rio com o Amazonas ("coisa completamente admirável e digna de ser conhecida"), os perigos e as condições da navegação (troncos, turbilhões, tempestades, ventos etc.), algumas características físicas, como a profundidade, a largura, as ilhas, "as várias alturas da água" e o regime pluvial. Algumas espécies de animais são mencionadas, ressaltando Brunelli que eram tantas as variedades de peixes que aqueles que se dedicavam à "contemplação das coisas naturais" iriam se "agradar ao máximo". O autor cita o peixe-boi (que julga ser um cetáceo), o poraquê (apresentado como 'torpedo'), o candiru (descrito como um inseto, sendo a mais antiga referência conhecida a este peixe) e os perigos que as ferroadas das arraias ofereciam aos descuidados, como o missionário franciscano que Brunelli vira falecer de gangrena, motivo pelo qual nunca mais pôde entrar nos rios para lavar o corpo. As aves e os mamíferos quase não são mencionados, mas as tartarugas e os jacarés sim, com todos os costumes humanos e as estórias relacionados a esses animais (Anexo 5).

Por fim, Brunelli problematiza o próprio nome do rio, supondo que Francisco de Orellana ${ }^{3}$ tenha visto guerreiras americanas com arco e flechas à mão e que, posteriormente, essa imagem tenha sido associada, com certo ridículo, às amazonas asiáticas - inclusive pelo "douto" La Condamine. Aqui, como no texto sobre a pororoca, o maior diálogo ocorre com o acadêmico francês, que Brunelli julga digno de ser citado, mas que considera pouco preciso e algumas vezes inseguro nas afirmações ${ }^{4}$. A pergunta que parece ficar nas entrelinhas de Brunelli é a seguinte: teria mesmo o famoso Condamine, então a maior referência científica sobre a Amazônia, visto o que declarou ter visto? Seu relato, que Brunelli considera um pouco fantasioso, mereceria crédito? Comparando sua própria experiência de oito anos na região com a breve passagem de Condamine, durante a qual teria 'ouvido falar' de tantas coisas, Brunelli faz a crítica ao texto do francês com a autoridade que seu testemunho garantia. O que estava em jogo nesse momento, e que aproxima a experiência do francês à do bolonhês, eram os critérios de cientificidade no estudo de uma região cercada de lendas e desafiadora para a empresa comercial europeia, ou o "método de provar", como menciona Brunelli. Essa mesma dicotomia entre fantasia e razão, esse esforço em discernir a certeza do provável (e do improvável), que aparece nos textos de Brunelli - e também nos de Condamine e de vários portugueses e luso-brasileiros, como Alexandre Rodrigues Ferreira - iria se prolongar por todo o século XIX em muitos relatos de naturalistas e exploradores que visitaram a Amazônia. Ela é, sem dúvida, uma das principais

3 Orellana desceu o rio Amazonas em 1541-1542. Ver relato da viagem em Papavero et al. (2002b, p. 15-41).

4 Sobre a viagem de Charles-Marie de La Condamine no Amazonas, no ano de 1743, ver Papavero et al. (2002b, p. 305-314). Sobre a obra de Condamine, ver Safier (2008).

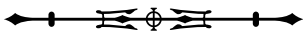


características de uma história das ciências e de uma história da literatura relacionada à região, como bem exemplificam os três textos de Brunelli.

Além desses textos, traduzidos pela primeira vez ao português a partir dos originais em latim, essa memória apresenta dois documentos do maior interesse para a história da Amazônia e das comissões demarcadoras portuguesas: um ofício de Brunelli endereçado ao ministro da Corte de Portugal, datado de 1752, no qual manifesta desgosto em ver-se preterido da coordenação dos trabalhos cartográficos na Amazônia, além de requerer aumento de salário e equipamentos adequados à tarefa, conforme acordado por ocasião de sua contratação em Bolonha (Anexo 1); e uma espécie de diário de viagem, que Brunelli rascunhou entre Belém e Mariuá (futura Barcelos) $)^{5}$, no rio Negro, em 1754 (Anexo 2). O primeiro, escrito em italiano, é uma contundente peça sobre os conflitos profissionais dentro da primeira comissão demarcadora, antes mesmo que ela começasse a funcionar, além de ser um interessante registro de disputas maiores entre astrônomos-matemáticos e os representantes de uma nova ciência que então se institucionalizava, a engenharia. $\bigcirc$ segundo, cujo original também se encontra em italiano, permite reconstruir o percurso da comissão, identificar a localização de engenhos e missões, antever a animosidade entre o governo português e os jesuítas, que mais tarde iria redundar na expulsão da ordem dos domínios lusitanos, entre outros aspectos. De ambos os documentos foram consultadas cópias existentes no Instituto Histórico e Geográfico Brasileiro (IHGB), no Rio de Janeiro.

Antes de seguir com os textos, convém apresentar uma breve nota biográfica de Brunelli, para melhor contextualizar sua produção intelectual e seus serviços ao governo português.

\section{NOTA BIOGRÁFICA DE GIOVANNI ANGELO BRUNELLI}

Sabemos que Giovanni Angelo Brunelli nasceu na Itália, muito provavelmente em Bolonha, em 22 de janeiro de 1722, e que morreu em 25 de fevereiro de 1804. Seu pai, Angelo Michele, morreu em 1800. Teve dois irmãos. Um deles, Giovanni Battista, falecido antes de 1797; foi casado e deixou um filho, Giuseppino ${ }^{6}$, e duas filhas'; sua viúva casou-se depois, em 1798, com um tal Sr. Mazzone, médico de Bolonhå. O outro irmão, Gabrielle, foi assistente de Eustachio Zanotti; morreu em 1797, aparentemente sem deixar família? .

Giovanni Angelo Brunelli era presbítero secular. Sem dúvida alguma, formou-se em astronomia, ingressando no Observatório Astronômico da Academia de Ciência do

\footnotetext{
5 Em 1728, o carmelita frei Matias São Boaventura fundou a missão de Nossa Senhora da Conceição de Mariuá (atual cidade de Barcelos, Amazonas). Em 1739, foi construída a capela de São Caetano e em 1744, a de Nossa Senhora de Santana. Em 1754, chegou a Mariuá o capitão-general Francisco Xavier de Mendonça Furtado para dar cumprimento ao tratado de limites entre Portugal e Espanha, ali permanecendo por vários anos. Em 1755, foi criada a Prelazia Geral. Em 1758, foi instalada a Capitania de São José do Rio Negro, com sede na Vila de Barcelos. Em 1791, passava a sede da capitania para o lugar da Barra (futura Manaus), mas retornando a Barcelos em 1799. A sede foi novamente para Barra em 1803.

6 Carta de A. Bianconi para G. A. Brunelli. Bolonha, 25 fev. 1799. BNRJ, Divisão de Manuscritos (Coleção Brunelli), I-04,25,013.

7 Carta de A. Bianconi para G. A. Brunelli. Bolonha, 30 out. 1797. BNRJ, Divisão de Manuscritos (Coleção Brunelli), I-04,25,005; Carta de A. Bianconi a G. A. Brunelli. Bolonha, 30 set. 1798. BNRJ, Divisão de Manuscritos (Coleção Brunelli), I-04,15,008; Carta de A. Bianconi a G. A. Brunelli. Bolonha, 13 ago. 1798. BNRJ, Divisão de Manuscritos (Coleção Brunelli), I-04,25,009.

8 Carta de A. Bianconi para G. A. Brunelli. Bolonha, 09 nov. 1798. BNRJ, Divisão de Manuscritos (Coleção Brunelli), I-04,25,011.

9 Carta de A. Bianconi para G. A. Brunelli. Bolonha, 14 ago. 1797. BNRJ, Divisão de Manuscritos (Coleção Brunelli), I-04,25,002; Carta de A. Bianconi para G. A. Brunelli. Bolonha, 21 ago. 1797. BNRJ, Divisão de Manuscritos (Coleção Brunelli), I-04,25,003; Carta de A. Bianconi para G. A. Brunelli. Bolonha, 16 set. 1797. BNRJ, Divisão de Manuscritos (Coleção Brunelli), I-04,25,004; Carta de A. Bianconi para G. A. Brunelli. Bolonha, 13 nov. 1797. BNRJ, Divisão de Manuscritos (Coleção Brunelli), I-04,25,006; Carta de A. Bianconi para G. A. Brunelli. Bolonha, 19 fev. 1798. BNRJ, Divisão de Manuscritos (Coleção Brunelli), I-04, 25,007; Carta de A. Bianconi para G. A. Brunelli. Bolonha, 1 out. 1798. BNRJ, Divisão de Manuscritos (Coleção Brunelli), I-04,25,010; Carta de A. Bianconi para G. A. Brunelli. Bolonha, 14 jan. 1799. BNRJ, Divisão de Manuscritos (Coleção Brunelli), I-04,25,012; Carta de A. Bianconi para G. A. Brunelli. Bolonha, 27 ago. 1799. BNRJ, Divisão de Manuscritos (Coleção Brunelli), I-04,25,014; Carta de A. Bianconi para G. A. Brunelli. Bolonha, 17 set. 1799. BNRJ, Divisão de Manuscritos (Coleção Brunelli), I-04,25,015.
}

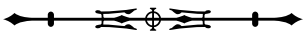


Instituto de Bolonha ${ }^{10}$. Em 1750, com Eustachio Zanotti, fez observações sobre um eclipse da Lua, publicadas na revista da Academia (Zanotti e Brunelli, 1755). Em junho do mesmo ano, foi contratado por João Álvares de Gusmão, padre carmelita descalço, para integrar a Comissão Demarcadora de Limites entre as possessões portuguesas e espanholas na América do Sul, em decorrência do Tratado de Madri, celebrado entre D. João V, de Portugal, e Fernando VI, da Espanha, em 13 de janeiro desse ano. Brunelli tinha, então, 28 anos. Segundo seu próprio testemunho, fora recomendado pelo Papa Bento XIV, bolonhês de nascimento (o papa que conferiu a D. João $\checkmark$ o título de 'Fidelíssimo'), tendo sido preferido a outros quatro candidatos (Anexo 1).

A 18 de julho, os técnicos contratados estavam em Gênova, aguardando a partida para Lisboa. Chegaram a essa capital em agosto. Ficaram retidos ali, por diversos acontecimentos, até junho de 1753. Entrementes, Brunelli escreveu um requerimento ao Ministro da Corte de Portugal exigindo instrumentos para a realização de observações astronômicas e insurgindo-se contra a nomeação de um agrimensor como chefe da comisão encarregada de levantar a carta da capitania do Grão-Pará (Anexo 1).

A 2 de junho de 1753, a comisão deixou Portugal, chegando em Belém a 19 de agosto. Os integrantes da comitiva permaneceram nessa cidade até 2 de outubro de 1754. A 11 de outubro de 1753 e a 6 de abril de 1754, Brunelli, com a ajuda de Landi, fez observações astronômicas, sobre as quais existem dois manuscritos: "Defectus Lunae observatus die sexta Aprilis apud Landi in Pará" e "Defectus Lunae die 30 Septembris 1754 in Pará apud Landi"11.

Os cientistas partiram rio Amazonas acima comandados pelo Governador e Capitão-General do Estado do Grão-Pará e Maranhão, Dom Francisco Xavier de Mendonça Furtado, em direção a Mariuá, no rio Negro. Meira Filho (1976, p. 572) publicou uma lista dos integrantes dessa expedição e os salários anuais devidos a cada um deles, como é possível observar na Tabela 1.

Brunelli recebia, portanto, enquanto na ativa, $50 \$ 000$ (cinquenta mil réis) por mês, já descontado o montante remetido a sua família. Segundo Vasconcelos (1999, p. 35), no período entre 1750 e 1777, uma dúzia de ovos custava 30 réis, um litro de azeite 146 réis e um grama de ouro 446 réis. $\bigcirc$ salário conferido a Brunelli dava, então, para adquirir 1.666 dúzias de ovos, ou 342 litros de azeite, ou 112 gramas de ouro, a cada mês. Seu salário mensal equivaleria hoje em dia (a $\mathrm{R} \$ 72,00$ o grama de ouro) a $R \$ 8.064,00$.

Acrescenta Meira Filho (1976, p. 572):

10 Eustachio Manfredi (Bolonha, 1674-1739), após frequentar a escola do convento dos jesuítas, dedicou-se primeiramente a estudos filosóficos, depois a jurídicos, formando-se em 1692. Com apenas 16 anos, organizava reuniões periódicas em sua casa. Desses encontros, nos quais eram discutidos filosofia e problemas de matemática, literatura e história, nasceu a Accademia degli Inquieti, por volta de 1690. Depois de quatro anos, entretanto, o grupo necessitava de mais espaço e as reuniões passaram a ser realizadas na casa de Jacopo Sandri. Com o desenvolvimento da carreira científica e acadêmica de Eustachio e com o crescente renome da Accademia, houve interesse em criar um instituto científico em Bolonha (Rime..., 1760). $\bigcirc$ principal idealizador do projeto foi o conde Luigi Ferdinando Marsigli (1658-1730). Esse ilustre militar bolonhês, geógrafo e naturalista, era membro de uma antiga família patrícia e teve educação esmerada. Prestou serviços a vários monarcas europeus, sobretudo na luta contra os turcos. Em meio a suas lides soldadescas, sempre encontrava tempo para devotar-se a atividades científicas. Em 1705, os encontros dos membros da Accademia degli Inquieti passaram a ter lugar no palácio de Marsigli, onde o conde havia instalado os mais modernos instrumentos vindos de Londres, Paris e da Alemanha. Em 1712, Marsigli decidiu doar toda a sua coleção e seus instrumentos para a cidade de Bolonha, com a condição de o Senado da cidade encontrar um lugar grande o suficiente para abrigá-los, onde seria estabelecido um laboratório de química e física, uma biblioteca, um observatório astronômico, com estipêndios para os professores. Após a aprovação da Santa Sé (lembremo-nos que Bolonha, nessa época, era parte dos Estados Papais), a 12 de janeiro de 1712, um ato notarial foi redigido para a doação que deslancharia o Instituto delle Scienze di Bologna. Escolheu-se para sua sede o palácio da família Poggi, considerado adequado para as atividades previstas. A Academia e o Instituto de Ciência foram inaugurados a 13 de março de 1714 e logo se tornaram famosos por toda a Europa. Em 1731, o Instituto iniciou seu periódico, onde Giovanni Brunelli iria publicar seus trabalhos sobre a Amazônia brasileira.

11 AHU, Brasil, Pará, caixa 14.

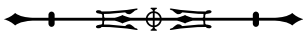


Tabela 1. Lista dos integrantes da Comissão Demarcadora de Limites (1753-1761) e sua respectiva remuneração (Meira Filho, 1976).

\begin{tabular}{|c|c|c|c|}
\hline & tem cada anno: & $\begin{array}{c}\text { deixa a sua família e acada anno se ha de } \\
\text { pagar a seu procurador no Conselho } \\
\text { de Vossa Magestade }\end{array}$ & \\
\hline Nomes & Ordenado & & Saldo \\
\hline Padre Ignacio Szentmartonyi & $180 \$ 000$ & Nada & $180 \$ 000$ \\
\hline João Angelo Brunelli & $800 \$ 000$ & $200 \$ 000$ & $600 \$ 000$ \\
\hline Sebastião José da Silva & $624 \$ 000$ & $312 \$ 000$ & $312 \$ 000$ \\
\hline João André Schwebel & $597 \$ 600$ & $240 \$ 000$ & $357 \$ 600$ \\
\hline $\begin{array}{l}\text { Gaspar João Gerardo de } \\
\text { Gronsfeld }\end{array}$ & $597 \$ 000$ & $336 \$ 000$ & $261 \$ 000$ \\
\hline $\begin{array}{l}\text { Gregorio Rebello Guerreiro } \\
\text { Camacho }\end{array}$ & $384 \$ 000$ & $240 \$ 000$ & $144 \$ 000$ \\
\hline Henrique Antonio Galuzzi & $386 \$ 400$ & Nada & $386 \$ 000$ \\
\hline Adam Lepoldo de Breuning & $120 \$ 000$ & Nada & $120 \$ 000$ \\
\hline Philippe Sturm & $240 \$ 000$ & $120 \$ 000$ & $120 \$ 000$ \\
\hline Manuel Gotz & $254 \$ 000$ & Nada & $254 \$ 000$ \\
\hline Antonio José Landi & $300 \$ 000$ & Nada & $300 \$ 000$ \\
\hline Daniel Panek & $240 \$ 000$ & $120 \$ 000$ & $120 \$ 000$ \\
\hline Antonio de Matos & $240 \$ 000$ & $36 \$ 000$ & $204 \$ 000$ \\
\hline Domingos de Souza & $240 \$ 000$ & Nada & $240 \$ 000$ \\
\hline \multirow[t]{2}{*}{$\begin{array}{l}\text { Francisco Xavier, criado do } \\
\text { padre Szentmartonyi }\end{array}$} & $86 \$ 400$ & Nada & $86 \$ 400$ \\
\hline & & & $\begin{array}{l}\text { Lisboa, } 23 \text { de maio de } 1753 \\
\text { Diogo Mendonça Corte Real }\end{array}$ \\
\hline
\end{tabular}

Dessa plêiade de homens responsáveis e excelentes técnicos, habilmente escolhidos pela Corte para os levantamentos das fronteiras entre as possessões portuguesas e espanholas na América Meridional, destacavam-se três Capitães: Schwebel, Gronsfeld e Rebelo Camacho; um tenente: Gotz; um SargentoMor: Sebastião José da Silva. Três Ajudantes: Galuzzi, Breuning e Sturm e dois Arquitetos 'desenhadores', Landi e Brunelli, ambos de Bolonha (Itália). O doutor João Angelo Brunelli, companheiro de Landi desde sua contratação, viria também como astrômomo e hábil pintor.

A viagem demorou 88 dias $^{12}$. Chegaram a Mariuá em 28 de dezembro, às nove horas da manhã. Brunelli deixou-nos um sóbrio relato dessa aventurosa e difícil viagem
(Anexo 2). A opinião de Mendonça Furtado sobre Brunelli, nada lisonjeira, encontra-se em uma sua carta de 13 de julho de 1755, dirigida ao futuro Marquês de Pombal, seu irmão:

ODr. João Ângelo Brunelli já veio de Lisboa com muito más ideias, introduzidas não sei por quem, mas é certo que quem fez esta obra nem amava os interesses do serviço de El-Rei, nem era grande meu amigo; e logo no princípio se deu a conhecer, como eu avisei V. Exa. naquela mesma frota; pela viagem [a Mariuá] fez uma quantidade de despropósitos que continuou aqui bastante tempo; hoje está em sossego. Deus queira que se não arrependa. É soberbíssimo e avarento em sumo grau e desconfiado. Dizem que sabe muito bem da sua profissão (apud Mendonça, 1963, II, p. 721).

\footnotetext{
12 Ver relato da viagem em Mendonça (1963, II, p. 615-631), Reis (1993, p. 276-290) e Papavero et al. (2002a, p. 23-42).
}

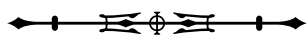


Os membros da comissão ficaram em Mariuá por longo tempo, esperando a sua contraparte espanhola, com a qual nunca chegariam a encontrar-se. Deixaram definitivamente essa localidade em 1758, chegando a Belém em 26 de dezembro.

Em 1759, Pombal decretou a expulsão dos jesuítas de todo o território português, continental, insular e ultramarino.

Em 1760, surgiu um incidente entre Brunelli e o bispo do Pará, Dom Frei Miguel de Bulhões e Sousa, do qual o astrônomo se queixou em carta (de 3 de março) a Francisco Xavier de Mendonça Furtado ${ }^{13}$.

Em 1761, Brunelli recebeu Ordem Régia para voltar ao Reino ${ }^{14}$, o que fez a bordo da charrua Nossa Senhora das Mercês, comandada pelo Capitão Domingos Dantas, viagem essa que custou cem mil réis para os cofres públicos $^{15}$. Em Portugal, exerceu o cargo de professor de Aritmética e Geometria na Academia Real da Marinha. Foi nomeado pelo rei D. José I professor de Filosofia e Matemática no Real Colégio dos Nobres, fundado pelo Marquês de Pombal em 7 de março de 1761.

No ano de 1767, publicou os trabalhos sobre a pororoca do rio Guamá (Anexo 3) e sobre a mandioca (Anexo 4). Em 1768, publicou uma tradução em português dos seis primeiros, do undécimo e do duodécimo livros dos "Elementos de Euclides" (Brunelli, 1768). Para esta tradução, serviu-se da versão latina de Federico Comandini e fê-la seguir de algumas notas com que Robert Simson (1687-1768) tinha ilustrado esta versão. Este livro foi outrora muito usado nas escolas portuguesas, razão pela qual se fizeram oito novas edições, até o ano de 1862.

Em 1769, aposentou-se do Colégio dos Nobres e regressou finalmente a Bolonha. Seu último trabalho, sobre o rio Amazonas, aparentemente lido perante a Academia de Bolonha em data incerta, foi publicado em 1791 (Anexo 5). Morreu em sua cidade natal aos 82 anos, em 1804.

\section{AGRADECIMENTO}

AMarina Zuccoli, bibliotecária do Observatório de Bolonha.

\section{REFERÊNCIAS}

BLUNT, W. El Naturalista. Vida, obras y viajes de Carol von Linné (1707-1778). Barcelona: Ediciones del Serbal, 1982.

BRUNELLI, J. A. De flumine Amazonum. De Bononiensi Scientiarum et Artium Instituto atque Academia Commentarii, v. 7, p. 39-54, 1791.

BRUNELLI, J. A. (Trad.). Elementos de Euclides dos seis primeiros livros de undecimo, e duodecimo da versão latina de Federico Commandino addicionados, e ilustrados por Roberto Simson... e traduzidos em portuguez para uso do Real Collegio de Nobres. Lisboa: Officina de Miguel Manescal da Costa, 1768.

BRUNELLI, J. A. De Pororoca. De Bononiensi Scientiarum et Artium Instituto atque Academia Commentarii, v. 5, n. 2, p. 249-255, 1767a.

BRUNELLI, J. A. De Mannioca. De Bononiensi Scientiarum et Artium Instituto atque Academia Commentarii, v. 5, n. 2, p. 334-344, 1767b.

CLUSIUS, C. Exoticorum libri decem, quibus animalium, plantarum, aromatum, aliorumque perigrinorum fructuum historiae describuntur. Item Petri Bellonius observationibus... Leiden: Officina Plantiniana Raphelengii, 1605.

CRISTOFOLINI, G.; BIAGI, M. D. Linneo a Bologna. Turim: Allemandi \& C., 2007.

D'ARTURO, G. H.; TEMPESTI, P. Piccola enciclopedia astronomica. Bolonha: Tipografia Compositori, 1960.

DOMINGUES, Ângela. Viagens de exploração geográfica na Amazónia em finais do século XVIII: política, ciência e aventura. Lisboa: Secretaria Regional do Turismo, Cultura e Emigração/Centro de Estudos de História do Attântico, 1991.

FERREIRA, A. B. H. Aurélio Século XXI. O dicionário da língua portuguesa. São Paulo: Editora Nova Fronteira, 1999.

LINNAEUS, C. Systema naturae per regna tria naturae, secundum classes, ordines, genera, species, cum characteribus, differentiis, synonymis, locis. 10. ed. Viena: Typis Ioannis Thomae nob. De Trattnern, 1758. Tomo I.

13 Ofício de João Ângelo Brunelli para o ex-Governador e Capitão-General do estado do Maranhão e Pará, Francisco Xavier de Mendonça Furtado. Belém, 3 mar. 1761. AHU_ACL_CU_013, caixa 45, documento 4178.

${ }_{14}$ Ofício do Governador e Capitão-General do estado do Pará e Maranhão, Manuel Bernardo de Melo e Castro, para o Secretário de Estado da Marinha e Ultramar, Francisco Xavier de Mendonça Furtado. Belém, 4 jun. 1761. AHU_ACL_CU_013, caixa 49, documento 4478.

15 Ofício do Governador e Capitão-General do estado do Pará e Maranhão, Manuel Bernardo de Melo e Castro, para o Secretário de Estado da Marinha e Ultramar, Francisco Xavier de Mendonça Furtado. Belém, 30 jun. 1761. AHU_ACL_CU_013, caixa 49, documento 4532.

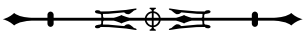


MARCGRAVE, G. Historia rervm natvralium Brasiliae libri octo. In: Historia naturalis Brasiliae. Auspicio et beneficio illustriss. I. Mauritii Com. Nasssau illius Provinciae et Maris summi Praefecti adornata. In qua non tantum Plantae et Animalia, sed Indigenarum morbi, ingenia et mores describuntur et iconibus supra quingentas illustrantur. Amsterdam: Franciscum Hackium \& Lud[ovicum] Elizevirium, Lvgdv[nvm], 1648. p. 1-283.

MEIRA FILHO, Augusto. Evolução histórica de Belém do GrãoPará. Belém: Grafisa, 1976. v. 1.

MENDONÇA, Isabel Mayer Godinho. Antonio José Landi (1713/1791): um artista entre dois continentes. Lisboa: Fundação Calauste Gulbenkian, 2003.

MENDONÇA, Marcos Carneiro de. A Amazônia na era pombalina: correspondência inédita do Governador e Capitão General do Estado do Grão-Pará e Maranhão Francisco Xavier de Mendonça Furtado (1751-1759). Rio de Janeiro: IHGB, 1963. 3 v.

MOURA, Carlos Francisco. Astronomia na Amazônia no século XVIII (Tratado de Madri): os astrônomos Szentmártonyi e Brunelli. Instrumentos astronômicos e livros científicos. Rio de Janeiro: Real Gabinete Português de Leitura, 2008.

MUNTEAL FILHO, Osvaldo. Uma sinfonia para o novo mundo: a Academia Real das Ciências de Lisboa e os caminhos da Ilustração luso-brasileira na crise do Antigo Sistema Colonial. 1998. Tese (Doutorado em História Social) - Instituto de Filosofia e Ciências Sociais, Universidade Federal do Rio de Janeiro, 1998.

PALCANI-CACCIANEMICI, L. De vita Eustachii Zanotti commentarius. Bolonha: Typographia Instituti Scientiarum, 1784.

PAPAVERO, N.; TEIXEIRA, D. M.; CAVALCANTE, P. B.; HIGUCHI, $H$. Landi, fauna e flora da Amazônia Brasileira. $O$ códice "Descrizione di varie piante, frutti, animali, passeri, pesci, biscie, rasine, e altre simili cose che si ritrovano in questa Cappitania del Gran Parà", de Antonio Giuseppe Landi (ca. 1772). Belém: Museu Paraense Emílio Goeldi, 2002a.

PAPAVERO, N.; TEIXEIRA, D. M.; OVERAL, W. L.; PUJOL-LUZ, J. R. O Novo Éden. A fauna da Amazônia Brasileira nos relatos de viajantes e cronistas desde a descoberta do rio Amazonas por Pinzón (1500) até o Tratado de Santo Ildefonso. 2. ed. revista e ampliada. Belém: Museu Paraense Emílio Goeldi, 2002b.

PAPAVERO, N.; LLORENTE-BOUSQUETS, J. Historia de la biología comparada desde el Génesis hasta el Siglo de las Luces. El Siglo de las Luces (Parte III). México: Universidad Nacional Autónoma de México, 2001. v. 7

PAPAVERO, N.; PUJOL-LUZ, J. R.; LLORENTE-BOUSQUETS, J. Historia de la biología comparada desde el Génesis hasta el Siglo de las Luces. El Siglo de las Luces (Parte I). México: Universidad Nacional Autónoma de México, 2001. v. 5.
$\mathrm{PISO}, \mathrm{G}$. De medicina brasiliensi libri quatuor. In: Historia naturalis Brasiliae. Auspicio et beneficio illustriss. I. Mauritii Com. Nasssau illius Provinciae et Maris summi Praefecti adornata. In qua non tantum Plantae et Animalia, sed Indigenarum morbi, ingenia et mores describuntur et iconibus supra quingentas illustrantur. Amsterdam: Franciscum Hackium \& Lud[ovicum] Elizevirium, Lvgdv[nvm], 1648. p. 1-122.

PROJETO RESGATE DE DOCUMENTAÇÃO HISTÓRICA "BARÃO DO RIO BRANCO". Catálogo de documentos manuscritos avulsos da Capitania do Pará existentes no Arquivo Histórico Ultramarino de Lisboa. Belém: Secretaria de Estado da Cultura do Pará, Arquivo Público do Estado do Pará, 2002. 3 v.

REIS, Arthur Cézar Ferreira. Limites e demarcações na Amazônia brasileira. A fronteira com as colônias espanholas. 2. ed. Belém: Secretaria do Estado da Cultura, 1993. v. 2.

REIS, Arthur César Ferreira. Limites e demarcações na Amazônia Brasileira. A Fronteira com as Colônias Espanholas. O Tratado de S. Ildefonso. Revista do Instituto Histórico e Geográfico Brasileiro, n. 244, p. 3-103, jul.-set. 1959

REIS, Arthur César Ferreira. Limites e demarcações na Amazônia brasileira. Rio de Janeiro: Imprensa Nacional, 1948. 2 v.

RIBEIRO, José Silvestre. História dos estabelecimentos scientificos, litterarios e artísticos de Portugal nos successsivos reinados da monarchia. Lisboa: Typografia da Academia Real das Sciencias, 1876. v. 6.

RIME di Eustachio Manfredi con un ristretto della sua vita e con alcune sue prose in questa nuova edizione aggiunte ed alcuni lugubri componimenti recitati in occasione della sua morte. Bolonha: Stamperia de Lelio della Volpe, 1760.

ROBUSTELLI, G. Inventário dos documentos da Coleção Brunelli. Anais da Biblioteca Nacional, Rio de Janeiro, v. 116, p. 187-218, 1996.

SAFIER, Neil. Measuring the New World. Enlightenment Science and South America. Chicago: The University of Chicago Press, 2008.

SANJAD, Nelson; PATACA, Ermelinda Moutinho. As fronteiras do ultramar: engenheiros, matemáticos, naturalistas e artistas na Amazônia, 1750-1820. In: COLÓQUIO LUSO-BRASILEIRO DE HISTÓRIA DA ARTE, 7., 2007, Porto. Actas... Porto: Faculdade de Letras da Universidade do Porto, 2007. p. 431-437.

SLOANE, H. A Voyage to the Islands Madera, Barbados, Nieves, S. Christophers and Jamaica, with the Natural History of the Herbs and Trees, Four-footed Beasts, Fishes, Birds, Inects, Reptiles \& c., of the last of these Islands; to which is prefix'd An Introduction, wherein is an Account of the Inhabitants, Air, Waters, Diseases, Trade, \& c. of that Place, with some Relations concerning the Neighbouring Continent, and Islands of America. Londres: Printed by B. N. for the Author, 1707. v. 1.

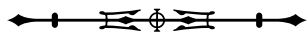


SLOANE, H. Catalogus Plantarum quae in Insula Jamaica sponte proveniunt, vel vulgò coluntur, cum earundem Synonymis \& locis natalibus, adjectis aliis quibusdam quae in Insulis Maderae, Barbados, Nieves, \& Sancti Christophoris nascuntur. Seu Prodromi Historiae Naturalis Jamaicae. Parte I. Londres: D. Brown, 1706.

SPIX, Johann Baptiste von. Animalia nova sive species novae Lacertarum, quas in itinere per Brasiliam annis MDCCCXVIIMDCCCXX jussu et auspiciis Maximiliani Josephi I. Bavaria Regis suscepto collegit et descripsit D. J. B. De Pix. Munique: Typis Franc. Seraph. Hübschami, 1825.

SPOTTE, S. Candiru: Life and legend of the bloodsucking catfishes. Berkeley: Creative Arts Book Company, 2002.

TEIXEIRA, Dante Martins. A imagem do paraíso. Uma iconografia do Brasil Holandês (1624-1654) sobre a fauna e flora do Novo Mundo. In: FERRÃO, C.; SOARES, J. P. M. (Eds.). Brasil Holandês. Introdução e Miscellanea Cleyeri. Rio de Janeiro: Editora Index, 1995a. Tomo I, p. 89-139.
TEIXEIRA, Dante Martins. Libri Principis. Rio de Janeiro: Editora Index, 1995b. v. 1.

TEIXEIRA, Dante Martins. Libri Principis. Rio de Janeiro: Editora Index, 1995c. v. 2.

TEIXEIRA, Dante Martins. Brasil-Holandês. Theatrum rerum naturalium Brasiliae. Ícones Aquatilium. Ícones Volatilium. Rio de Janeiro: Editora Index, 1995d.

TEIXEIRA, Dante Martins. Icones Animalium Brasiliae. Icones plantarum Brasiliae. Rio de Janeiro: Editora Index, 1995e.

VASCONCELOS, P. O "real" valor do "dinheiro". 850 anos de história da inflação em Portugal. Sacavém: Sociedade Difusora de Cultura, 1999.

ZANOTTI, Eustachio; BRUNELLI, Giovanni. Observatio eclipsis Lunae habita... die 19 lanuarii MDCCL. De Bononiensi Scientiarum et Instituto atque Academia Commentarii, v. 3, p. 359-361, 1755. 
Anexo 1. Requerimento de Brunelli ao Ministro da Corte de Portugal pedindo que sejam exatamente cumpridas as condições estabelecidas em Bolonha, quando foi contratado para vir ao Brasil, ca. 1752.

Algumas reflexões para as quais solicito [...] de Vossa Excelência antes que eu seja anexado à presente expedição que se faz por parte de Sua Majestade Fidelíssima ao Brasil, para levantar o mapa geográfico daquele país.

Havendo eu sido procurado em Bolonha para a presente expedição, na qualidade de astrônomo, pelo Reverendíssimo Padre Álvares de Gusmão, a quem Sua Santidade se dignou propor-me e preferir-me a quatro outros matemáticos, ou seja, ao Padre Vincenzo Ricaro, jesuíta, a dois padres leitores dominicanos e ao senhor Álvaro Mancucci, substituto na profissão astronômica no Observatório de Bolonha, aceitei vir sob as condições que esse Reverendíssimo Padre deveu expedir para a Corte, porém supondo que devesse subsistir tudo aquilo de que então me interei. Mas já que vejo as coisas presentemente mudadas e com cara diversa, venho rogar que Vossa Excelência pondere algumas coisas que, se não forem alteradas, não será possível que eu queira expor-me a tantos perigos e fadigas, que necessariamente devem ser encontrados por todos aqueles que estão para ir ao Brasil.

Em primeiro lugar, não pretendo de maneira alguma ser anexado a uma expedição, quando, posto que deva haver um diretor geral, não seja ele um dos matemáticos que foram aceitos, e não um simples engenheiro, tal como o senhor Coronel Miguel de Blasco, o qual, de sua própria boca, fez-me saber que seria ele o diretor geral da carta que se deve fazer do Brasil. Porque, em tal caso, cada um dos matemáticos convidados fica grandemente prejudicado e perde sua honra, sendo coisa totalmente vergonhosa que um simples engenheiro, vale dizer no nosso caso um simple medidor prático ou agrimensor, dirija os matemáticos, pelos quais ele tem extrema necessidade de ser dirigido e apoiado, junto com todos os outros que a ele estão subordinados atualmente, assim como seria coisa vergonhosa que um simples cirurgião-barbeiro superintendesse um grupo de médicos e dirigisse suas operações. E quanto a mim em particular, saiba Vossa Excelência, que a isto não me posso de modo algum submeter, devendo manter com todo zelo o decoro de minha Univesidade e da Academia de Bolonha, da qual fui levado, e juntos devemos de certa maneira prestar contas de minhas ações a Sua Santidade, que se dignou fazer-me uma honra tão distinta sobre todas as outras.

E para que ninguém diga que falo sem razão, saiba-se que, tratando-se de fazer uma carta geográfica de um país qualquer, não basta, como diz o dito senhor Coronel, que se engenha em dizer que a Astronomia de nada serve neste assunto, não basta, digo, pôr na planta pouco a pouco aquele trecho do país por que se vai passando, coisa de todo material e que pertence ao medidor prático, ou seja, ao engenheiro, mas necessariamente, de lugar a lugar, devem-se tomar as longitudes e latitudes e fazer outras observações, sem as quais não se pode tornar perfeita a carta tal como deve ser e tal como entendo que se exige. É, portanto, claro que o Astrônomo é aquele que concorre principalmente para a construção da carta geográfica; mesmo porque na própria medição muitas vezes ocorrem certos casos em que o próprio medidor deve ser assistido de maneira particular pelo Matemático, de modo que, sem a direção destes, esse medidor nada pode fazer.

Ao fazer esta projeção da Carta Geográfica Geral deve-se ter muitos cuidados, que dependem de princípios sobre os quais o medidor prático ou o simples engenheiro talvez nunca tenha pensado.

Além disso, tudo o que pode fazer este medidor pode ser feito ainda pelo matemático, e com maior fundamento, enquanto nem tudo o que pode fazer o matemático pode ainda fazer o medidor ou perito.

Por isto foi sempre costume louvável que, juntando-se Matemáticos e Engenheiros ou agrimensores para alguma operação de compromisso, a direção de todo o negócio ser dada sempre a um dos Matemáticos, dos quais devem depender, em tudo e para tudo, os Engenheiros.

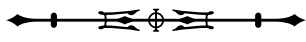


Em segundo lugar, em caso de ter eu a honra de passar ao Brasil para servir Sua Mejestade Fidelíssima na qualidade de Astrônomo, não posso, sem prejuízo de minha honra, deixar que a carta daquele trecho do País, através do qual passarei fazendo medições, saia em nome de outrem, porque ela depende principalmente de minhas observações.

Atualmente, não exijo nada mais do que me foi prometido pelo Reverendíssimo Padre Gusmão. Esse Reverendíssimo Padre assegurou-me que cada matemático, além de todas as outras honrarias, teria seu nome passado para a carta [...] com suas direções e com suas observações astronômicas, e nem teria eu feito um tal acordo sem que antes tivesse sabido o teor destes assuntos.

Em terceiro lugar, tendo-me sido concedida pelo dito Padre Reverendíssimo a soma de 800.000 réis por cada ano, e a metade dessa soma devendo ser-me paga depois da expedição durante toda minha vida, mesmo estando em minha casa, supondo-se que esses senhores Engenheiros, cujo estipêndio esse Padre dizia não chegar à dita soma, fossem verdadeiramente matemáticos capazes de fazer observações matemáticas e depois achando-se que muitos deles não chegavam nem a ser bons Engenheiros, e cujo estipêndio é quase o mesmo que o meu, deixando de parte o senhor Coronel, que tem quase o dobro daquilo que me foi concedido, suplico reverentemente [a $\mathrm{V}$. Excia.] que reflita que não me pagam aquilo que proporcionalmente deviam [...], tanto mais razoáveis quanto melhores [...] esses senhores Engenheiros.

Esta é minha súplica [...]; depois de chegar a Lisboa tendo-se-lhes concedidas novas vantagens, principalmente a da metade do estipêndio pela vida, no caso de que depois das viagens ou pelas fadigas da expedição se tornem incapazes de ganhar a vida, vantagem esta que antes não tinham, e eu entretanto permaneci na mesma condição de antes, com pouco crédito e menos lucro.

Pelo contrário, a mim parece-me, com toda a aparência de verdade, que minha condição [piorou] em Lisboa, tanto que [...], entre minhas obrigações [...], tive que ensinar a meus companheiros as práticas das observações astronômicas, não sei com que êxito, mas sim sei que com muito incômodo.

Em quarto lugar, rogo a Vossa Excelência ponderar atentamente que minha honra e minha reputação não me permitem de maneira alguma que eu embarque para o Brasil enquanto não me forem dados bons instrumentos, isto é, aqueles que forem absolutamente necessários para as operações astronômicas que devem ser feitas nas expedições. Pois, sem tais instrumentos, não poderei desempenhar-me honradamente nem Sua Majetade poderá ser por mim bem servido.

Os instumentos necessários são os seguintes, tal qual me foram prometidos pelo Padre Reverendíssimo.

Um quadrante de suficiente tamanho, ou seja, cujo raio seja de cerca de 30' 4 pés, sem defeitos e fornecido de todo o necessário.

Dois relógios de pêndulo, porque sendo o relógio de pêndulo um instrumento sujeito a desarranjar-se facilmente, no caso de um quebrar outro esteja logo em prontidão, sendo este instrumento sumamente necessário para as observações astronômicas.

Mesmo que me fossem dadas algumas pessoas práticas e sabedoras do mister, das quais pudesse servir-me nas operações a meu bel-prazer e independentemente de qualquer outro que comigo possa estar na mesma brigada, não pretendo aceitar um assunto e um compromisso de tanta fadiga.

São estas as condições sob as quais pretendo querer servir, da melhor maneira que puder, a Sua Majestade Fidelíssima, sem as quais não posso de maneira alguma permanecer nesse serviço. Se forem justas tais condições e razoáveis os pedidos, rogo que me seja dado ouvido; se, entretanto, não forem aceitos como tais, não saberei o que dizer, se não que me foi contrária a fortuna.

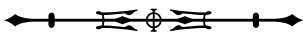


Anexo 2. Roteiro escrito por Brunelli da viagem do Governador e Capitão-General do Estado do Grão-Pará e Maranhão, Francisco Xavier de Mendonça Furtado, com a Comissão Demarcadora de Limites, de Belém a Mariuá, no rio Negro, de 2 de outubro a 25 de dezembro de 1754.

\section{2 de outubro de 1[7]5[4] [Quarta-feira]}

Por volta das dez horas, após a partida do [Capitão-]General e de seu séquito, pus-me em minha canoa para começar a viagem em direção ao rio Negro.

1 - Engenho de Burajuba, dos jesuítas, onde produzem açúcar, obtêm muito cacau e café; haverá mais de sessenta pessoas no serviço. Para chegar a este lugar desde o Pará [Belém], é necessária cerca de uma hora. Tem igreja. À mão esquerda.

2 - Lugar de Domingos Serrão - À mão esquerda - vizinho à boca do Moju.

3 - Engenho de Jaguarari, dos jesuítas, com igreja - À mão esquerda - apenas entramos no Moju.

4 - Ribeira - Lugar com engenho de açúcar; aqui são fabricadas as canoas do rio. Cheguei a este lugar pela tardinha e todos aqui permaneceram à noite.

Embarcamos por volta das 10 horas.

\section{Dia 3 [Quinta-feira]}

5 - Engenho da Taboca, com igreja - À mão esquerda.

6 - Engenhoca de Olarambaba - à direita. Estão construindo uma igreja.

7 - Engenhoca de Guajará, com igreja. À mão esquerda.

8 - Engenho Gequiri, com igreja - À mão esquerda. Alguns lugares não observados.

9 - Engenho Guajará. À mão esquerda - onde paramos quase toda a tarde, partindo por volta das oito horas e chegando depois à boca do Igarapé-Miri, onde existe uma engenhoca.

$10-$ [incompleto]

Dia 4 [Sexta-feira]

Por volta do meio-dia entramos no Igarapé-Miri; no início é muito estreito e dificultoso; depois, pouco a pouco, alargase e torna-se um grande rio.

11 - Paramos ao meio[-dia]; depois do almoço fomos para Santana - À direita.

\section{Dia 5 [Sábado]}

Depois do almoço partimos de Santana; o bispo [D. Miguel de Bulhões], após muitas cerimônias, partiu para - Pará [Belém] com seu séquito e outros senhores. À tarde paramos onde o canal, já há muito alargado, encontra uma ilha que o divide como em dois outros canais, um oposto ao outro - 12 - No caminho vê-se uma engenhoca.

\section{Dia 6 [Domingo]}

Pouco depois de erguer-se o Sol, chegamos à boca da primeira baía de Marapatá - Missa na floresta - Já tínhamos partido por volta da meia-noite; vários lugares durante a viagem.

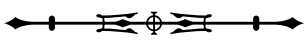




\section{Dia 7 [Segunda-feira]}

Antes de raiar o dia, com um vento bastante forte e bom, passamos as duas bocas de Marapatá [...] parando no local de [...] com engenho e igreja [...] e a viagem [...] por volta das 5 horas. Depois do almoço, à uma hora, partimos do dito lugar e por volta das 7 horas, sempre prosseguindo por um labirinto de ilhas, atingimos as bocas da terceira baía de Maraguaru.

\section{Dia 8 de outubro [Terça-feira]}

Cerca de duas horas antes de raiar o dia, passamos pela dita baía de Maraguaru, que é muito longa, mas não tão larga, assim que sempre se viam pelos lados muitas ilhas de diversa grandeza. Percorremos este caminho por cerca de três horas, chegando ao lugar de Pedro Furtado, com igreja e engenho, situado na grande ilha de Joanes, ainda dita de Marajó. Por volta das três da tarde, partimos do dito lugar, passando pela baía das Bocas e parando às 7 horas em Marajó, na boca de um rio que passa entre a grande ilha de Joanes e outras ilhas.

\section{Dia 9 [Quarta-feira]}

Partindo de manhã, antes de raiar o dia, terminamos com a dita baía das Bocas e entramos em outras águas muito largas, parando por toda a tarde e noite subsequente.

\section{Dia 10 [Quinta-feira]}

Partimos pela manhã, antes de raiar o sol, sempre caminhando por um canal muito largo, até chegar à baía de Aricuru e à aldeia desse nome, dos padres jesuítas. Chegamos por volta do meio-dia. A aldeia não tinha uma alma, coisa da qual se lamentou muitíssimo o [Capitão-]General a um dos dois padres missionários, que todavia não era o principal. As casas dos índios são muito miseráveis, palafitas, construídas com paus finos e cobertas de palha. O número de almas pode ser de 1.200.

\section{Dia 11 [Sexta-feira]}

Às 11 horas, partimos de Aricuru em direção a Urucará, onde chegamos por volta das 2 horas. Essa aldeia é maior que a outra, as casas são as mesmas, as almas serão por volta de 2.000; poucos estavam na aldeia. Está situada não muito longe da boca do rio Pajujás. Dormi em terra (junto ao) [Capitão-]General.

\section{Dia 12 [Sábado]}

Passada uma hora depois do meio-dia, partimos da dita aldeia e, depois de haver passado por águas muito largas, entramos em um canal $[. .$.$] que é muito longo parando todos à noite bem escura.$

\section{Dia 13 [Domingo]}

Antes do raiar do dia, prosseguindo nossa viagem pelo dito canal, paramos por volta das 10 horas para a missa na floresta. À uma retomamos nosso caminho, caminhando até as 51/2. O canal alarga-se num certo lugar até chegar a conter uma ilha bastante grande.

\section{Dia 14 [Segunda-feira]}

Por volta das 4 horas, retomamos nosso caminho. Seguindo este grande canal, que já contém várias outras ilhas; repousamos até as 10. Depois, à uma e meia, outra vez a caminho, parando às 4; por temor do mau tempo, (não) prosseguimos a viagem até por volta das 7.

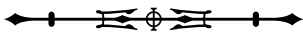




\section{Dia 15 [Terça-feira]}

Em marcha por volta das 3 1/2, tomando a rota de Macapá; já feito dia, subitamente voltamos para Gurupá; labirinto de várias ilhas. Paramos às [...]. Às 4 a caminho. Subitamente, devido ao mau tempo, parados por uma hora; daqui caminhamos até às 7.

\section{Dia 16 [Quarta-feira]}

Pela manhã, como de costume, em marcha, parando durante algum tempo para esperar o [Capitão-]General; caminhouse depois até as 11. Às 4 1/2 a caminho; paramos à hora habitual.

\section{Dia 17 [Quinta-feira]}

Como de hábito, em marcha logo pela manhã. Às 11, paramos em águas muito largas que formam uma baía chamada Avaquiá. Aqui paramos por todo o dia e a noite seguinte. Apenas fez-se noite, mau tempo.

\section{Dia 18 [Sexta-feira]}

Às 5 1/2 em marcha, até uma hora após o meio-dia. Tendo ficado um pouco para trás, depois do almoço, entretanto, juntamo-nos aos outros. Águas largas.

\section{Dia 19 [Sábado]}

Raiado o dia, em marcha, chegando às 9 3/4 no miserável forte de Gurupá. Há aqui um convento de capuchinhos. São poucos frades; há uma outra igreja miserável. Lugar de brancos.

\section{Dia 20. Domingo}

Fiz limpar a canoa metendo-a debaixo d'água, havendo tido uma casa. Depois do almoço [fui a] uma pequeníssima aldeia a um quarto de milha de distância.

Dia 21. Segunda-feira

Parados.

\section{Dia 22. Terça-feira}

De manhã embarcou-se tudo [...] pouco depois das oito. Parti, chegando depois do meio-dia ao lugar de Estêvão Cardoso, com igreja, de onde partimos pela tardinha, parando por volta das 9 1/4, protegidos por uma ilha.

\section{Dia 23. Quarta-feira}

Às 7 horas em marcha. Às 9 1/2, paramos na aldeia Aiapijó, dos capuchinhos.

\section{Dia 24. Quinta-feira}

Às [...] horas, depois dos outros, partido da dita aldeia, chegando às 2 na aldeia Caviana, dos capuchinhos. Antes das [...] partimos. Cerca das [...] horas parados em um lugarejo com igreja, chamado Japará. Antes deste, algumas miseráveis cabanas $[\ldots]$.

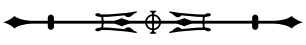




\section{Dia 25. Sexta-Feira}

Partimos por volta das 10, tendo chegado pouco antes o Padre S. Martim [Inácio Szentmártony], de Macapá [...] passados a almoçar com o [Capitão-]General. Passando por Boa Vista, atingimos [...] em Maturu às 3 horas. Entre Boa Vista e Maturu, existem pedras com algum perigo. Aqui começa o rio Xingu. Esta aldeia, como as outras dos capuchinhos, recebeu bem o [Capitão]-General.

\section{Dia 26. Sábado}

Às [...] 1/2, depois de uma grande perda de tempo por causa de índios [fugidos?], que precisei substituir, partimos da dita aldeia de Maturu. Pouco depois, entramos num canal de tamanho médio, chamado Aquiqui, parando por volta do meio-dia. Às 3, outra vez em marcha até as oito. Neste canal existem insetos chamados 'carapanãs', que são uma espécie de pequenos mosquitos. Numa e noutra margens [...] veem-se campos amplos e sem árvores.

\section{Dia 27. Domingo}

Antes do raiar do dia em marcha, pelo dito canal que continua sendo pouco mais ou menos da mesma largura. Paramos às 10 horas. Às 2 em marcha, até passado às 7. Às 4 1/2 deixamos o Aquiqui, à mão direita entramos no Guajará, com aproximadamente a mesma largura.

\section{Dia 28. Segunda-feira}

Às 3 em marcha, parando depois das 10 1/2, aproximadamente [... na floresta. A noite passada incomodíssima pelos carapanãs. À 1 1/2 em marcha outra vez até as [...] 1/2, parando numa boca que entra no rio Amazonas. Antes disso, o rio se dividia em vários ramos mais largos; a boca chama-se de Guajará.

Dia 29. Terça-feira

Ao levantar-se o Sol, em marcha até as [...] horas, parando em uma ilha muito grande antes que os outros.

\section{Dia 30. Quarta-feira}

Às 7 1/2 em marcha, quando vimos juntarem-se o [Capitão-] General e os outros. Passada a dita ilha às 10 1/2, achamonos diante da aldeia de Urubuqu[ara], dos capuchinhos, à mão direita, sobre uma pequena colina [...] restavam muitas [...]. Às 3 paramos. Apenas caída a noite, ergueu-se um fortíssimo vento entre [...] por [...] vizinho.

\section{Dia 31. Quinta-feira}

Às 4, em marcha. Pelo meio-dia, em frente a Curupatapu, que fica terra adentro, à direita, a uma viagem de cerca de um dia. Neste lugar, há uma grande ilha que cobre as margens. Às [...] horas e meia paramos.

\section{Dia $1^{\circ}$ de novembro. Sexta-feira}

Às 3, em marcha, até às 8 1/2; missa na floresta. Às [...] outra vez em marcha até por volta das [...] horas, até uma ilha; aqui as terras são mui altas, muita pedra e terra amarela.

\section{Dia 2. Sábado}

Por volta das 4, em marcha até a tarde, parando numa ilha.

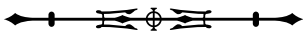




\section{Dia 3. Domingo}

Antes das três, em marcha até às 7. Missa na floresta, e depois chuva e trovões. Às 10, em marcha até depois das 4, parando quase em frente a um lago e uma outra grande ilha que lhe estava à frente; todo o dia de hoje contornamos uma grandíssima ilha.

\section{Dia 4. Segunda-feira}

Durante toda a viagem, ilhas grandes e ricas. Por volta das 4, partimos, chegando à vila do Tapajós às 8 1/2. [...] vila, como as outras destas partes, é muito miserável, com um [...] pouco distante junta-se à aldeia governada por um Padre da Companhia [...] dos melhores, e as casas não são tão feias. Ficamos para dormir na casa do missionário. Muito mal.

\section{Dia 5. Terça-feira}

[...] manhã. Fui com L. [Landi?] e [...] a uma casa que eles tinham antes.

\section{Dia 10. Domingo}

Às 6 1/2, retomamos a marcha, mas com grande lentidão por duas horas, mas depois com bom vento. Para retomar ao rio Amazonas é necessário regressar um pouco atrás. Caminhamos até às 8 da noite, sem jamais repousar. O Padre Inácio [Szentmártony] ficou com o missionário por estar indisposto.

\section{Dia 11. Segunda-feira}

Por volta de uma hora antes de raiar o dia, em marcha. Quase às 11, paramos dentro de um canal que prossegue muito adentro até um grande lago, pelo qual se pode ir por um [...] a Pauxis [Óbidos].

\section{Dia 12. Terça-feira}

Às 3, em marcha até às 7 da noite e chegamos a Pauxis [Óbidos]. Eu entre os últimos. Pela manhã, muito vento. Atravessamos o rio [Amazonas].

\section{Dia 13. Quarta-feira}

Em terra pela manhã. A fortaleza de Pauxis [Óbidos], como de costume, é pequena e miserável, mas antiga e colocada num lugar muito eminente; há uma pequeníssima aldeia anexa dos capuchinhos. Aqui, o rio Amazonas é estreitíssimo.

\section{Dia 14. Quinta-feira}

Depois das 7 1/2, partimos de Pauxis [Óbidos]. Paramos ao meio-dia na boca do Trombetas.

\section{Dia 15. Sexta-feira}

Por volta das 4 1/2, partimos da dita boca e paramos uma meia hora depois do meio-dia. Às [...] 1/2, em marcha até às 8. Passamos o rio para andar, entre ilhas, até um lugar seguro.

\section{Dia 16 de novembro. Sábado}

Pela manhã, às 4, em marcha até às 9. Depois, ao meio-dia, outra vez em marcha até às 3, parando entre ilhas, entre as quais caminhamos todo este dia. Na noite subsequente, quantidades de carapanãs.

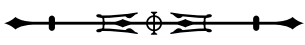




\section{Dia 17. Domingo}

Às $41 / 2$, em marcha até depois das 7. Missa na floresta. Às 9, outra vez em marcha até cerca das 9 da noite. Paramos numa ilha.

\section{Dia 18. Segunda-feira}

[Antes do raiar do] dia, trovões e relâmpagos e chuva. Feito o dia, em marcha entre ilhas até às 11 1/2. [...] ilhas num longo estreito, vizinhas a uma areia descoberta, que nas marés altas se alarga.

\section{Dia 19. Terça-feira}

De madrugada, grande chuva e vento; [...] choveu bastante todo este dia, e por isto ficamos parados no mesmo lugar.

\section{Dia 20. Quarta-feira}

Antes de raiar o dia, em marcha, mas no início pouca viagem, depois com bom vento [...]. Depois das [...] viajamos; águas mais largas, mas sempre algumas ilhas.

\section{Dia 21. Quinta-feira}

Das 4 da manhã até por volta das $23 / 4$, com bom vento, sempre entre ilhas.

\section{Dia 22. Sexta-feira}

Entre às 4 e 5, em marcha até depois do meio-dia, entrando em um como canal medíocre. Depois do almoço, chuva e mau tempo. Às 8 da noite, em marcha até depois da meia-noite.

\section{Dia 23. Sábado}

Depois das 6 horas, em marcha até passado o meio-dia. Parados em um lugar muito baixo. Grande chuva. Depois das 3 , em marcha outra vez, parando depois de quase 2 horas de viagem. $\bigcirc$ canal alarga-se.

\section{Dia 24. Domingo}

Às 5, em marcha. Às 8, missa na floresta e logo após em viagem até por volta das 5. Muitas terras coloridas. $\bigcirc$ rio agora muito largo. À mão direita.

\section{Dia 25. Segunda-feira}

Depois das 4, em marcha até às $81 / 2$ da noite. Entre os últimos. Rio largo e sempre alguma ilha. Viajamos sempre à mão direita. Bom vento em parte.

\section{Dia 26. Terça-feira}

Pela manhã, cedíssimo, em marcha. Ao meio-dia, passamos por ilhas onde se produz manteiga de tartaruga. Chama-se Saracá. Bom vento. Parados às $21 / 2$ na boca de um rio estreito. Depois do almoço, quase todas as canoas voltaram para tomar tartarugas e manteiga.

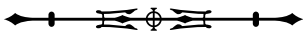




\section{Dia 27. Quarta-feira}

Pela manhã, antes de raiar o dia, tempo um pouco feio. Depois do almoço, as canoas regressaram com tartarugas. Mas ficamos parados no mesmo lugar.

\section{Dia 28. Quinta-feira}

Às 7, em marcha [...] até a tarde, sempre à mão direita. Ficamos cobertos por uma ilha.

\section{Dia 29. Sexta-feira}

Às 7, em marcha. Durante a viagem, sempre alguma ilha. À tarde, às 5, parados, cobertos por uma ilha, vizinhos de pedras $[\ldots]$ uma vez.

\section{Dia 30. Sábado}

Às [...] em marcha. Depois das 6, missa na floresta. Depois das 7, em marcha até as 3 1/2. Sempre ilhas, entre as quais paramos às $[\ldots] 1 / 2$. Mas $[\ldots]$.

\section{Dia $1^{\circ}$ de dezembro. Domingo}

Às 4, em marcha até às 8 1/2. Missa na floresta. Logo depois em marcha. Pouco antes do meio-dia, em frente à boca do rio Madeira, sempre à mão direita. Sempre ilhas [...] paramos à tarde. Grande correnteza e muitas pedras sob a água, com perigo [...] terras e pedras coloridas na margem.

\section{Dia 2. Segunda-feira}

Feito dia, passamos por toda parte pedras sob a água, que deram o que fazer a todos, e depois caminhamos até por volta das três, parando por temor do mau tempo num lugar estreito e seguro, entre ilhas.

\section{Dia 3. Terça-feira}

Por volta das três, em marcha em águas estreitas entre ilhas, mas perderam-se quase duas horas por causa de ter a canoa grande encalhado. Antes do almoço, antes de sairmos num canal mais largo, paramos numa praia muito espaçosa por um bom par de horas por temor do mau tempo; depois, em marcha até a noite, eu um dos primeiros a parar num bom lugar.

\section{Dia 4. Quarta-feira}

O dia todo parados para descanso do pessoal.

Dia 5. Quinta-feira

Pela manhã, às 4, em marcha, mas muito devagar. À mão direita [...] algumas ilhas. Ao pôr do Sol, paramos.

\section{Dia 6. Sexta-feira}

Ao erguer-se o Sol, em marcha. Gastamos mais de uma hora e meia para passar uma corredeira sobre pedras. Às 7 $1 / 2$, outra vez em marcha. Por volta das 10, uma outtra corredeira, perdemos pouco mais de meia hora. Em marcha até o pôr do Sol, parando em uma ponta de pedra. Sempre à mão direita e ilhas.

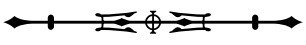




\section{Dia 7. Sábado}

Ao erguer-se o Sol, passamos por outra corredeira, gastando bastante tempo. Depois das 11, chegamos à fortaleza do rio Negro. Terras altas.

\section{Dia 8. Domingo}

Depois de haver ouvido missa em terra - tudo aqui é miserável - em marcha às $91 / 4$ até as $31 / 2$. Terras sempre elevadas. Sempre à mão direita. Pedra.

\section{Dia 9. Segunda-feira}

Depois das 6, em marcha. Bastante pedra na margem direita. À uma hora paramos. Não sei por quê.

\section{Dia 10. Terça-feira}

De dia, em marcha. De repente, uma grande ilha à mão esquerda, depois muitíssimas, entre as quais à tarde paramos. Mas eu, ao meio-dia, por uma hora [...].

\section{Dia 11. Quarta-feira}

Às 8, em marcha até as $41 / 2$, sempre por uma canal estreito em meio a ilhas.

Dia 12. Quinta-feira

Às 5, em marcha sempre entre ilhas, até à uma e meia. Labirinto de ilhas.

\section{Dia 13. Sexta-feira}

Às 5, em marcha. Passadas as [...] caminhando por terra firme à esquerda. Desapareceu um índio, pelo qual paramos até às 4 1/2. Depois, caminhamos por três horas, chegando já escuro onde estavam os outros. Infinitas ilhas.

\section{Dia 14. Sábado}

Às 5 1/2, em marcha, terra firme à esquerda. Sempre terras amuradas, que parecem pedra. Ilhas sem número. Paramos à uma e meia, longe das grandes pedras no meio d'água.

\section{Dia 15. Domingo}

Às 6, em marcha. Depois da missa, a caminho até às 5. Terra firme à esquerda. Baixios, pedras e ilhas.

\section{Dia 16. Segunda-feira.}

Às 5, em marcha. Às 11, fomos ver as pedras escavadas. Às 3, paramos. Sempre à esquerda, pedras e ilhas.

Dia 17. Terça-feira

Por volta das 5, em marcha. Sempre pedras e ilhas. Às 10, chegamos à aldeia dos Carmelitas, chamada Jaú, à esquerda, que vi durante a tarde e, como de costume, miserável.

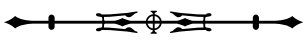


Dia 18. Quarta-feira

Às 7, em marcha até a noitinha, sempre entre ilhas. Caída a noite, um vento fortíssimo, que depois, por quase toda a noite, fez chover, com relâmpagos e trovões.

\section{Dia 19. Quinta-feira}

Às 6, em marcha entre ilhas; às 9, parados por uma hora, depois a caminho, até às 5.

Dia 20. Sexta-feira

Às 5, em marcha. Às 10, chegamos à aldeia, em terra firme, à esquerda, dos Carmelitas, chamada Pedreira e com o nome indígena de Puhure, como de costume miserável. O Padre Madalena, que dois dias antes veio encontrar-se, com outros, com o [Capitão-]General, disse missa com o canto das [...]. Às 5 da tarde, eu, com o Sargento [...] fomos à frente, ficando todos os outros na aldeia. $O$ [Capitão-]General recebeu nesta aldeia muitas honras. Sempre muitas ilhas. Paramos às 8 1/2, quase por uma hora, depois em marcha. Quando chegamos à dita aldeia, grande chuva, trovões. Muitas ilhas durante a viagem.

\section{Dia 22. Domingo}

Havendo viajado toda a noite, chegamos às 11 horas na aldeia Guaracari, dos padres Carmelitas. É pior que as outras [...] o caminho sempre entre ilhas, e depois com terra firme à esquerda. Missa e depois, às 2, em marcha até por volta das 10. Depois da dita aldeia, não se veem pedras de nenhum tipo. Por volta da meia-noite, chuva.

Dia 23. Segunda-feira

Na noite passada, depois de haver o pessoal repousado por 2 horas, em marcha, sempre entre ilhas, à noitinha paramos por uma hora, depois em marcha.

Dia 24. Terça-feira

Boa parte da noite, em marcha. Paramos por certo tempo depois do almoço, pouco antes das duas até às 3 1/2. Águas largas, terra firme à esquerda e ilhas à direita. Às 6, chegamos a Cumaru, aldeia dos padres Carmelitas. Paramos para a missa do Natal, celebrada pelo missionário. Às 3 1/2, partimos.

\section{Dia 25. Quarta-feira}

Não mais havendo interrompido a viagem, cheguei à tarde em Mariuá. Fui para o Hospício. Pouco, pouco antes de chegar, abriu-se-me a canoa, opondo-se um mau tempo. Também choveu pela manhã.

Tradução de Nelson Papavero.

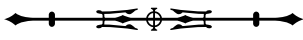


Anexo 3. "Sobre a Pororoca".

Giovanni Brunelli. Sobre a pororoca.

Carta de Giovanni Brunelli a Eustachio Zanotti.

Saudações.

Há tempo tenho pensado cá comigo, caríssimo Zanotti, que nada daquelas coisas que acontecem no mundo pode passar despercebido dos que apreciam dedicar-se à contemplação da natureza. Com efeito, quando algo de novo ou não costumeiro aparece, cuja causa seja necessário investigar, penso que todas as forças da inteligência devem ser colocadas à prova e também que se deva ser diligentemente cuidadoso para que, se, por acaso, algo for esquecido, ainda que pouco importante ou pequeno, as coisas que não conseguiram ser entendidas ou explicadas não pareçam ter sido omitidas de propósito. É por isso que resolvi, de forma breve, porém cuidadosa, como puder, expor-te uma coisa grandiosa em primeiro lugar e admirável, sobre cujo fenômeno gostaria de ouvir de ti, que superas em inteligência e cultura até os filósofos de nossa terra, alguma causa. Se perceberes aqui algumas deduções da minha impressão, de modo que as vejas trazer para mim alguma claridade em tão grande escuridão, saibas não ficar com essa impressão. Quis somente testar a inteligência, e tentei o que por acaso poderia dizer, porque parecia provável. Pois então conhece agora o que ninguém, e por isso com maior prazer, encarregou-se, até aqui, que eu saiba, de tratar. Há uma cidade na América do Sul chamada Pará [Belém], ao lado de um rio, que dista um grau e quase meio ao sul do Equador; e do oceano, na verdade, para o qual se volta, entre as regiões oriental e norte, cinquenta milhas e mais. $\bigcirc$ rio que banha a cidade situada no litoral meridional, acrescido, eu diria, antes, com muitas águas que são trazidas através de torrentes de todas as partes e por rios menores que para aí confluem ao entrar no oceano. Por outro lado, o litoral extremo do Amazonas, que entra no mesmo oceano, dista da cidade espalhado num longo espaço com inúmeras ilhas, das quais uma, que os índios chamam Marajó, se concentra num círculo traçado em torno de quase 500 milhas. E daí deduzes facilmente quão seriamente se enganam os que afirmam que a cidade do Pará [Belém] está situada na zona meridional do rio Amazonas. Tratarei, porém, desse erro de alguns geógrafos em outra ocasião, quando empreender a discussão sobre o próprio rio Amazonas. Entre aqueles menores rios que, como disse pouco antes, trazem águas para a cidade do Pará, há um que se chama Guamá, na linguagem americana. Nele há, entre outras, uma ilha, na verdade de pequeno contorno, mas muito célebre e muito reconhecida por toda a vizinhança, distante da mesma cidade cerca de 45 milhas e ficando com quase 200 passos de extensão no meio do rio. Aí, como acontece com outros rios que estão mais perto do oceano, diariamente acontecem duas cheias e duas vazantes do mar, quando a Lua não está longe da sizígia. No seguinte, no outro e no terceiro dia após a Lua nova ou Lua cheia, quando as maiores de todas as ondas chegam longe, um pouco além daquela ilha que mencionei há pouco, de repente uma força enorme e um volume de águas exuberante irrompe tão rapidamente que, num tempo curtíssimo, se elevam todas impulsionadas até lá onde antes ou depois de outros dias sobem num intervalo de seis ou sete horas. Os índios chamam esse súbito e violento ímpeto das águas de 'pororoca'. Com esse vocábulo exprimem bastante convenientemente a velocidade da água, o medo dos navegantes e, quem sabe também o perigo. Na verdade, chamam ilha da 'pororoca' a ilha onde a pororoca começa. Em resumo, um horrendo fragor começa a ser ouvido, quando três a três, ou quatro a quatro, as ondas brancas em espuma se precipitam com todo o ímpeto daquela ilha, abatendo-se sobre elas mesmas, e, lançadas para o alto e a toda volta, inundam amplamente os campos, num enorme espaço. Então, arrebatam consigo,

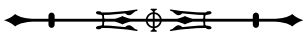


com grande força, troncos de árvores, cadáveres de animais, canoas, enormes pedras e tudo o que encontram no meio do caminho. Onde o rio tem um leito mais estreito ou se dispersa em rios menores, tamanho é o ímpeto da pororoca e tamanha a força que as águas parecem enfurecer-se inteiramente. Assim, a pororoca lança-se para o alto através dos rios que encontra, até que, pouco a pouco, perdidas as forças, volta finalmente ao repouso e desvanece completamente, quando as águas já atingem a maior altura. Embora a pororoca fique muito mais fraca que no dia anterior e tenha ímpetos muito menores, no terceiro dia, assim mesmo deve ser temida. No tempo que dura a pororoca, principalmente a maior, que vem logo depois da própria união ou da oposição, quem estiver navegando naquele trecho do rio situado acima da ilha da 'pororoca' deve tomar extremo cuidado para que ela não o surpreenda e ele se condene pelo ato. Realmente, ouvi dizer que muitos assim morreram desgraçadamente; conversei com um homem que, quando navegava naquela parte do rio, e ouvia, parecia-lhe, o fragor da pororoca ainda bastante longe, disse-me poder apenas ter subido com os companheiros numa árvore das mais altas, quando, então, viu a canoa posta abaixo dele ser arrebatada com uma velocidade incrível pelas ondas e finalmente afundar. Entretanto, ainda que haja todas as forças da 'pororoca' e o ímpeto para as partes superiores do rio, como disse acima, não queria que acreditasses que, onde nasce, principalmente nos lugares não muito distantes da ilha da 'pororoca', não acontece nenhuma agitação tumultuosa de águas que se chocam. Com efeito, não é possível acontecer que, daquela ilha, tão grande força e tão grande volume de águas irrompa subitamente, com tanta altura, porque alguma parte, com o seu peso, cairá de alto a baixo na parte contrária do rio. As águas do oceano e as da 'pororoca' avançando em sentido contrário devem provocar movimentos muito fortes de águas, de tal forma que possam trazer medo aos navegantes e também perigo, até que todas as águas, por toda parte, naquele trecho do rio, se acalmem como que para a igualdade das forças. As maiores 'pororocas' de todas, porém, são as que acontecem depois dos equinócios, habitualmente passada a Lua de sizígia. Efetivamente, as águas da estação irrompem para fora com a maior abundância e mostram forças em toda parte muito violentas e temíveis. Até agora expus aquela 'pororoca' que ocorre no rio Guamá, no qual tive a oportunidade de navegar duas vezes, e quase todos os habitantes da vizinhança da cidade podem facilmente ver e observar. Mas, em outros lugares mais distantes da cidade também acontecem outras 'pororocas' quase nas mesmas épocas; dessas, a maior de todas, sem dúvida, é a que se desencadeia com uma rapidez sobremaneira gigantesca e com a maior força, a mais temível de todas, quase na própria foz do rio Amazonas, perto daquele promontório que chamam de Cabo do Norte. Aí, La Condamine, quando navegava para a ilha de Caiena, por negligência dos índios, quase morreu, como ele mesmo atesta. Agora, então, Zanotti ilustríssimo, antes de começar a expor-te o que pensei sobre a causa desse fenômeno, queria que soubesses que contam os habitantes daquele lugar muitas coisas de caráter muito obscuro e difićlimas de explicar, que me parecem mais ridículas do que dignas de crédito, para que sejam trazidas a exame. Alguns acreditam que a 'pororoca' se origina constantemente por causa da força do mar, as águas são impelidas para o alto com maior ímpeto do que com o que costuma o rio desaguar no oceano. Se isso fosse assim, em qualquer parte das terras, o mar se enchendo com a agitação, os rios teriam sua 'pororoca', que seria observada facilmente por todos, duas vezes todos os dias. Por que nunca é vista nenhuma 'pororoca' abaixo da cidade do Pará, bem entendido, naquele trecho do rio em que tantas águas de outros rios e de menores correntezas, afluentes de todas as partes, se chocam com águas marinhas com forças muito maiores? Por que nesse mesmo rio Guamá, onde a força do mar quase sempre avança muito lentamente, um pouco acima daquela ilha que tantas vezes mencionei, a 'pororoca' de repente irrompe com tanta violência e tão gigantesca rapidez? E ainda, por que isso sempre ocorre depois que passou a Lua de sizígia? Estou omitindo muitas outras coisas sugeridas por aqueles homenzinhos ignaros, para não te provocar mau humor e

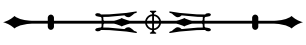


náusea. Volto-me, pois, para aquilo que, após cuidadoso exame do fato, penso poder-se dizer, de certa forma, sobre a investigação da causa desse tão obscuro fenômeno; apesar disso, algumas coisas envolvem dificuldades não desprezíveis, mas, de alguma forma, parecem ser essas as prováveis causas. $\bigcirc$ que se pode ter como certo, acima de tudo, e que está solidamente conforme a observação, é que a própria 'pororoca' está ligada com a agitação do mar, de forma que parece depender claramente disso, porque fica muito patente, conforme o que eu disse acima. E, assim, o próprio movimento marítimo seria facilmente a causa dessa horrenda erupção de águas. Na verdade, quem disser isso assim secamente, não explicará nada completamente e tornará o fato muito difícil, obscuro e absolutamente inexplicável, como era. Portanto, a explicação deve ser esclarecida, como as ondas agitadas do mar, que sempre são notadas após a conjunção da Lua e do Sol, ou pela oposição, durante alguns dias, muito maiores do que em todos os outros, poderiam fazer com que tanta força e uma massa de água irrompam afora naquele lugar onde a 'pororoca' começa. Como eu poderia dizer com poucas palavras como isso acontece? Acho que, pouco acima da ilha da 'pororoca', há uma abertura muito ampla de um canal oculto e que sai no mar, não longe da costa, por baixo das terras, em passagens invisíveis. É certíssimo que existem esses canais assim subterrâneos, pelos quais as águas ocultas são levadas aos lugares tão bem descritos, e só pode ignorar isso quem nada tiver ouvido. Penso, pois, que por esse canal aquela tão grande quantidade de água e tanta força com que a 'pororoca' se manifesta são levadas até aquela ilha pela própria gravidade, e que se lançam para fora, de forma, entretanto, a não sair alta em frente, mas subindo por um caminho oblíquo, por causa do duto do canal, com uma rapidez gigantesca contra a força do rio. E deve-se dizer que isso acontece incontinente, e aquela ameaça da maior agitação do mar acima da abertura do canal abate-se toda por onde ela mesma acaba no mar. Isto estabelecido, pois, quando pouco depois de sizígia as águas marinhas produzem aquela cheia muito maior que todas as outras, poderia talvez acontecer que essas mesmas águas ganhassem também maior altura, acima da mesma abertura do canal, do que aquelas que se conservam perto da ilha da 'pororoca', as quais, com certeza, em pouco tempo são levadas para o mar. Portanto, as águas marinhas que entram no canal devem ser levadas pelo mesmo, com o próprio e natural peso, até aquela ilha, com a maior velocidade e com o maior ímpeto, o que é exigido pela lei dos fluidos, até que todas as águas, as que estão no rio e as que chegam do mar pelo canal, ganhem altura absolutamente igual. E isso deve acontecer no mais breve espaço de tempo, todos os que olham a natureza dos fluidos entendem facilmente. Por outro lado, em outros dias, quando, certamente, a Lua está longe da sizígia, visto que aquela cheia não atinja tal altitude, por que não dizermos, nas águas que se lançam, porventura, na abertura do canal, que têm então a mesma altitude, da forma como acontece em canos, que haja a mesma intensidade, de uma parte e de outra, das forças que se estreitam? Nenhuma 'pororoca' haverá nesses dias, pois deve ser bastante grande e rapidíssima, e deve acabar num tempo muito curto, toda vez que a Lua se aproxima do Sol ou dele se distancia. Facilmente também entenderás por que a Lua estando em sizígia, no tempo dos equinócios, as 'pororocas' apresentam-se muito maiores. Então ocorrem as maiores de todas as ondas marinhas, e por essa razão aquela cheia também aparece com a maior altura, ou seja, como as águas do mar entram no canal com maior força, também irrompem para fora no rio com a maior abundância, velocidade e força. Enfim, como aquele canal subterrâneo no mar acaba não longe da costa, penso poder explicar mais tranquilamente por que a 'pororoca' sempre aparece na mesma época em que as águas se lançam do mar para o alto através dos rios. Portanto, aquela cheia não se lança inteira acima da abertura daquele canal do mar, sem que antes as águas cheguem à costa pouco a pouco e se introduzam por todos os lados nos rios. Agora tens, ilustríssimo Zanotti, meu julgamento sobre a 'pororoca', ou, antes, alguma conjectura; que mesmo que agrade pouco, não a exponho com má vontade, nem, acredite-me, me irrito. Por que não relatar essas ideias com as quais, quaisquer

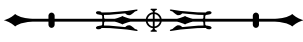


que sejam, esta minha conjectura pode ser derrubada? O que é preciso esconder quem procura mais a verdade do que o louvor da inteligência? E o mais importante, quando o mar recua e volta para dentro dele mesmo, um redemoinho muito amplo deveria ser formado junto à ilha da 'pororoca', por causa da correnteza impetuosa de água nos dutos subterrâneos. Que eu saiba, porém, nenhum redemoinho é observado em todo esse intervalo de tempo, em que as águas do rio são vistas correndo para o mar. Será possível que, naqueles lugares, perto do oceano, durante esse tempo, as águas mantenham essa mesma altitude? Se, pois, assim fosse, não se poderia esperar redemoinho algum. De fato, se afirmo isso, não queria dizer que seja verdade. Aprendi bastante com a observação que, quando a agitação se acalma, a superfície das águas, quanto mais perto do mar, tanto mais baixa é. Na verdade, o que segue traz uma dificuldade muito maior. Na mesma perspectiva da cidade do Pará, durante todo esse tempo em que as águas descem para o mar, vê-se um redemoinho muito perigoso, que se estende numa volta amplíssima por todos os lados, que eu mesmo já atravessei algumas vezes, com medo. E realmente, quando voltava do rio Negro para a cidade, lembro-me que a canoa em que viajava, quando mal atingiu a borda do redemoinho, desviou-se aos poucos do curso e, por fim, com grande força foi levada para o meio. Escapei desse perigo junto com os companheiros por pouco, pelos maiores esforços dos remadores. Ouvi dizer que muitos pereceram naquele redemoinho, cujos cadáveres nunca apareceram. Assim também muitas canoas são absorvidas, que ninguém nunca mais pôde ver de novo. Grandes e frondosas árvores, por outro lado, o que frequentemente acontece, fixam-se no centro do turbilhão, primeiro se erguem e depois, com uma enorme força, se afundam de tal forma que não são mais vistas em lugar nenhum. Contudo, quando o mar se enche com agitação, nenhum redemoinho tão grande aparece aí e desaparece completamente. Não posso garantir com segurança que seja do mesmo gênero daqueles que chamam de vivos, mas eu não navegaria com facilidade; isso que acabo de contar gera uma suspeita não desprezível, da mesma forma que demonstra que esse redemoinho é assim formado pelas águas que escoam pelo canal oculto. Se é assim o que dissemos, por que nenhuma 'pororoca' houve nesse lugar, com o mar cheio e agitado, do mesmo modo que aconteceu no rio Guamá e em outros lugares? Talvez aquele canal, se é que existe, não acabe no mar, mas vá para outro lugar, e para lugares remotíssimos. Na verdade, quem disser isso, diga-me também, e com clareza, se é possível, explique por que aquele redemoinho não aparece sempre, mas somente quando as águas voltam para o mar. Portanto, se aquele turbilhão tem sua origem nas águas que se escoam pelo canal oculto que se estende até o mar e, no entanto, essas águas não voltam depois pelo mesmo canal, e em algum momento se lançam para fora, produzindo a 'pororoca', a conjectura que acima fiz para explicar a mesma 'pororoca' cai inteiramente e não existe nenhuma daqui para a frente. Mas, caríssimo Zanotti, eu próprio não tive que esconder essas coisas, eu que reconheço ignorar a causa verdadeira de um fenônemo admirável, no entanto, desejo veementemente conhecê-la. É o que tinha para te escrever sobre a 'pororoca'. Se tratares dessa tarefa com nossos acadêmicos, não só deixar-me-ás grato, como também ter-me-ás cada vez mais obrigado a ti. Na verdade, acho que aqueles grandes homens, por causa da novidade do assunto, ouvirão de bom grado essas coisas. Se com a maior inteligência, em que eles se sobressaem, perscrutarem alguma causa que pareça ser pertinente ao assunto, coloca-me imediatamente a par. Adeus.

Tradução de Abner Chiquieri.

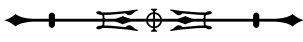


Anexo 4. "Sobre a mandioca".

Giovanni Brunelli.

Sobre a mandioca.

Carta a Ferdinando Bassi.

Diletíssimo Ferdinando Bassi: já que te aplicas inteiramente à contemplação das coisas da natureza e por essa dedicação te conquistas um grande louvor e te relacionas brilhantemente com a própria história natural, com descobertas nada desprezíveis, pareceu-me que não te serei de forma alguma desagradável se te escrever algo que tem a ver, de algum modo, com os teus estudos, e que, ao mesmo tempo, é encantador e digno de conhecimento. Por essa razão eu mesmo me propus a dizer algo sobre uma planta que se cultiva em muitas e grandes regiões da América, e que é chamada pelos povos do Brasil de 'Maniba' ou 'Maniva', e expor-te num breve discurso os principais usos dessa planta. Notabilíssimos botânicos, entre os quais Guilherme Piso e George Marcgravea , que me agradam muito, descreveram assim a planta. E Piso, na verdade, enumera nove espécies da planta. Mas pode acontecer que sejam muito mais ${ }^{\mathrm{b}}$; e esse ilustríssimo senhor terá chamado pelos nomes diferentes de diversas nações uma mesma espécie. Com efeito, também os americanos, conforme as várias distâncias das regiões entre si, fazem uso destas ou daquelas línguas, embora se fale de uma única origem derivada da antiga gente 'Tupinambá', já desaparecida, comum a quase todos esses povos. Também o ilustríssimo senhor Linnaeusc', no livro que escreveu sobre os gêneros das plantas, descreve a flor da mandioca, ainda que com outro nome. Tournefort ${ }^{d}$ mostra a figura do fruto e da flor dessa planta; mas Plukenet e Sloane $e^{\dagger}$ apõem também a figura da planta inteira. Começarei, pois, pela cultura da planta, que requer grande cuidado e algum trabalho.

Os americanos, depois de construir e preparar o viveiro, descartadas as mudas que não querem usar, tiram os ramos verdes e fortes, bem como os brotos novos das plantas adultas da 'Maniva' e arrancam as folhas. Fincam na terra os ramos reduzidos a um tamanho aproximado de dois pés ou menores, de forma, contudo, com que a parte do ramo que era inferior na planta conserve o mesmo lugar também sob a terra. E não distribuem cada ramo numa mesma

a [Nota dos editores: trata-se de Guilherme Piso (Leiden, 1611 - Amsterdam, 1678) e Jorge Marcgrave (Liebstadt, 1610 - Angola, c. 1644), que vieram para o Brasil como cientistas trazidos pelo conde Maurício de Nassau-Siegen, durante o período em que governou o Nodeste brasileiro (1737-1644), então sob ocupação holandesa. Escreveram, em 1648, partes da "Historia naturalis Brasiliae". Tanto Piso (1648, p. 48, 52-55) quanto Marcgrave (1648, p. 65-68) dissertaram sobre a mandioca e sua preparação, como cita Brunelli. Para detalhes sobre a obra de Piso e Marcgrave e uma edição dos desenhos originais de plantas e animais preparadas pelos artistas contradados por Nassau, que serviram de base para as xilogravuras da "Historia naturalis Brasiliuae", ver Teixeira (1995a, 1995b, 1995c, 1995d, 1995e)].

b [Nota dos editores: são, atualmente, conhecidas cerca de 100 espécies e quase 2.000 variedades do gênero Manihot (Euphorbiaceae), ao qual pertence a mandioca (Manihot utilissima)].

c "Genera Plantarum". Paris, 1743. Gen. 867. Jatropha. Atque sub hoc genere species septem enumerat, in quibus ea, quae quintum tenet locum, eadem est ac illa de qua in praesens agimur; vocaturque ab ipso Cel. Linnaeo Jatropha (Manihot) foliis palmatis; lobis lanceolatis integerrimis laevibus. Caroli Linnaei species plantarum, Holmiae, 1763, p. 1429. [Nota dos editores: trata-se de Carolus Linnaeus (17071778). Para biografia e obras, ver Blunt (1982) e Papavero e Llorente-Bousquets (2001)].

d "Institutiones rei herbariae". Paris, 1700, p. 658. Tab. 438. [Nota dos editores: trata-se de Joseph Pitton de Tournefort (1656-1708). Ver Papavero et al., 2001, p. 121-125)].

e "Almagestum", [1696], p. 241. t. 205. f. 4. [Nota dos editores: trata-se de Leonard Plukenet (1641-1706)].

f Ricinus minor, viticis obtuso folio, caule verrucoso, flore pentapetala albido, ex cujus radice tuberosaq, succo venetato turgidae, Americani panem conficiunt. Sloanus "Cat. plant. Jamaicae Hist." 1. p. 130. t. 85. [Nota dos editores: trata-se de Hans Sloane (1660-1753), que publicou, em 1696, o "Catalogus plantarum quae in insula Jamaica sponte proveniunt", onde forneceu um elenco de autores que escreveram sobre a mandioca na América Latina, nos séculos XVI e XVII (Sloane, 1706). Em sua "Voyage..." (Sloane, 1707), ilustrou na prancha 85 a planta da mandioca e na prancha 141, a raiz].

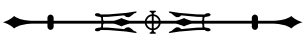


cova, mas três a três ou quatro a quatro, e assim colocados na parte mais funda do buraco, se distanciem em pequenos intervalos com as covas cheias de terra, também erguem um montículo, de forma que pareçam naturalmente apenas sair da terra as pontas mais altas das ramas. Separam com intervalos de pelo menos três pés os pares de covas, que ficam perto uma da outra. É preciso, por outro lado, que a terra seja bem triturada e bem solta. Porque, se torrões maiores e mais duros envolverem os ramos, estes produzirão raízes mais doentias e menos abundantes. Os agricultores cuidam também diligentemente de não fazer a plantação quando estão iminentes ou já caem as chuvas maiores. $\bigcirc$ trabalho deles seria em vão, com as ramas todas apodrecendo ou com a maior parte cheia de muita água. Muitas e muitas vezes, depois de plantar as ramas, o mato deve ser arrancado e as ervas variadas e muitas que crescem com admirável rapidez e retiram as seivas e quase toda a força da terra. Cada uma das ramas que, após poucos dias, se transforma em planta, produz três, quatro, mas até cinco ou seis raízes, se a terra for fértil e ótima; ao contrário, produzirá somente duas, se a terra for estéril e arenosa. As raízes a que é atribuído o nome de 'Mandioca' ou 'Manioca' não têm o mesmo tamanho nem a mesma forma. Umas são maiores, outras, menores; algumas nascem quase redondas; muitas também crescem em comprimento, que atinge, nas maiores raízes, a grossura de meio pé, por vezes dois pés e mais. Muitas raízes, ainda, costumam ser premiadas com uma imagem que não se pode definir facilmente. A cor da casca, conforme a variedade da espécie das raízes, é diferente, a saber: quase preta, branca, violácea ou quase amarela. Igualmente a polpa, em cujas raízes resplandece com um branco brilhante bastante elegante, ou, em outras, como a gema do ovo, tinge-se de uma cor completamente amarela. Delas se fabrica o melhor tipo de farinha. Todas as raízes, não importa a terra em que crescem, só podem conseguir maturidade no espaço de quase um ano, atingindo o tamanho justo e perfeito, como dizem. Apesar disso, se os índios sentirem necessidade, premidos pela fome, não hesitam em arrancá-las da terra ainda no fim do quinto mês. Com essas raízes, no entanto, como elas ainda não estão maduras, quando cruas, parecem poder preparar pouca coisa de bom. Por outro lado, as terras pretas e férteis, onde alguma selva mais densa foi cortada e queimada, fazem crescer de modo admirável e produzem a planta da 'Maniva' que chega quase à estatura de um homem grande. Mas, em qualquer outro tipo de terra, ainda que seja estéril, até nas areias dos rios, desde que se mostrem espaçosas em alguns lugares, por alguns tempos, a planta cresce e se nutre desse modo, embora devam finalmente dar raízes menores e piores. Disse, como pude, da cultura da planta da mandioca. Agora, caríssimo Bassi, explicarei com poucas palavras os principais usos dessa planta.

E, para começar, deve parecer admirável que uma planta cheia de veneno mortífero enquanto verde e cheia de suco satisfaça como pão a uma incrível multidão de homens. Os americanos, portanto, assim como também muitos povos na África, das raízes dessa planta fabricam diversos tipos de farinhas e muitos outros de iguaria e alimento, da mesma maneira que nós também costumamos extrair de todos os tipos de trigo muito sustento para nossa vida. Antes vou enumerar e descrever alguns poucos instrumentos de que os americanos costumam servir-se para esse fim.

Ainda que os índios, principalmente os bárbaros, não disponham de ferro, fabricam-se um ralador, que chamam de ibicé, para ralar as raízes em fragmentos miúdos, da seguinte maneira. Recolhem, por toda parte, pequenos e agudos seixos, que, se for preciso, quebram com uma pedra muito dura, e partem todos em pedrinhas menores iguais o quanto possível e todas igualmente angulosas. Fixam essas pedrinhas numa tabuinha, com as pontas agudas para cima; e assim as dispõem de forma que as bases das pedras se juntem umas às outras, e constituam juntas como que linhas retas. Então, com pez liquefeito colocado por cima e somente arrefecido, as pedrinhas aderem à tábua tão fortemente que não podem daí ser arrancadas com facilidade. Desses raladores, os índios, que costumam preparar a farinha para poucos dias, usam muito mais frequentemente que os europeus. Estes, aliás, como devem frequentemente fazer uma

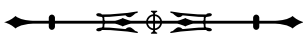


grande quantidade de farinha, para ralar as raízes mais rapidamente, recorrem a uma roda de madeira presa de pé a um círculo mais largo, cuja extremidade externa da roda um pouco exposta na largura cingem em toda volta com uma folha de ferro maleável, áspero por toda parte e perfurada com inúmeros furinhos. As raízes, então, postas com a mão na roda, enquanto impelida com extrema velocidade no círculo, são moídas em pedaços rapidamente lançados para fora.

Os americanos inventaram também outro instrumento, com o qual extraem o suco das raízes já quebradas e moídas. De um caniço tenro, que chamam de 'varumá'a com o qual costumam fabricar esteiras e uma grande quantidade de outras coisas do gênero, tiram a casca e cortam-na aos pedaços, em comprimento. Da casca assim preparada tecem um cilindro comprido de grossura média, que chamam 'tipiti', bem fechado na parte de baixo e aberto em cima, de forma que, levado de lá para cá, possa ser facilmente conduzido para o lado oposto, sendo a capacidade diminuída no interior de todo o cilindro. Por essa razão, acontece que, enquanto o cilindro fica suspenso, todo cheio de pequenos fragmentos de raiz, se da parte interior desse cilindro for pendurado um peso maior, os fragmentos se comprimem de todos os lados e todo o suco escorre por si mesmo. Os europeus, contudo, que são mais apressados, costumam usar moinhos ou outros maquinários do gênero.

Com a mesma casca cortada mais fina, os índios fabricam também diversas peneiras de forma quadrada, em grande quantidade, a que dão o nome de urupema. Com essas peneiras, reduzem de algum modo os fragmentos das raízes já moídos e quase isentos de suco pela fricção e, ao mesmo tempo, os purificam.

Para poder esmagar as raízes quebradas e já moídas quantas vezes for necessário, fabricam do tronco duríssimo de uma árvore um pilão, chamado na língua americana inuá.

Enfim, fabricam panelas planas e regulares de diversos tamanhos, mas de forma redonda, em que torram no fogo as farinhas e tudo o que fazem com as raízes da mandioca. Qualquer que seja o tamanho da panela, tem o nome de japuná.

Mas agora vejamos o que os habitantes da América fazem com as raízes da mandioca e expliquemos, enfim, os principais usos dessas raízes, especialmente no Brasil. Começarei pela farinha, que chamam de cicab, fabricada deste modo: com a ajuda de uma faca, primeiro livram as raízes da casca e lavam com água para limpar as sujeiras; em seguida, com o ralador ou com a roda que acima descrevi, ralam-na em fragmentos miudíssimos. Com o cilindro acima mencionado, ou com o uso do moedor, espremem o suco; então socam os fragmentos no pilão e imediatamente levam-nos de novo para o cilindro para extrair o líquido restante para novamente socar. Principalmente porque querem ser mais cuidadosos, costumam repetir isto tantas vezes até que o suco todo tenha saído e, ao mesmo tempo, passem até os menores fragmentos de mandioca. E, na verdade, isso deve acontecer sempre assim, o que basta lembrar uma vez, todas as vezes que algo precisar ser feito das raízes da mandioca. Em seguida, os fragmentos, livres de quase todo o líquido e selecionados pela peneira, são estendidos sobre uma panela quente com fogo embaixo, tomando-se o maior cuidado para que o fogo não seja forte demais, nem que os fragmentos fiquem muito tempo sobre a panela sem mexer. É por essa razão que moderam, se for preciso, a força do fogo, e agitam com algum enfornador os próprios fragmentos, que espalham em volta de toda a largura da panela com um movimento constante, até que todos estejam secos igualmente e bem torrados. Desse modo, se faz a farinha cica, com os pedaços transformando-se quase em pequenos grãos um pouco amarelados. Assim, a farinha alimenta muito bem e costuma ser conservada por muitos meses ou até por mais de um ano, se for feita com muito cuidado e toda umidade for afastada. É conservada em cestos

\footnotetext{
[Nota dos editores: provavelmente, a tala das folhas da palmeira guarumã (Ischnosiphon arouma (Aubl.) Koern.)].
}

b [Nota dos editores: segundo Ferreira (1999, p. 467), o termo vem do tupi e significa 'pegajoso'].

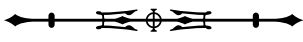


cujo nome é uruçacanga [aturá] ou panacu [jamaxim], que os índios tecem com um vime chamado 'timbó', ou com aqueles caniços cortados em toda extensão a que demos acima o nome de 'varumá'. Os índios revestem esses cestos, por todo o interior, com as folhas mais duras de certo gênero de palmeira, ou seja, 'ubim'. A farinha que acabamos de descrever costuma ser chamada pelos índios de uí cica.

A farinha que os europeus chamam d'água, e os índios uí catu, saborosíssima quando fresca e feita segundo o costume, os americanos preparam deste jeito. Mantêm as raízes da mandioca seis ou sete dias dentro da água, até que a casca possa ser tirada com a mão, sem nenhum esforço quase. É, então, que prestam muita atenção para que as raízes não fiquem demais na água. Podem estragar facilmente e apodrecer horrivelmente. As raízes liberadas da casca, como estão muito moles, imediatamente se dissolvem em fragmentos. Em seguida, extraem daí apenas o suco a que nos referimos antes e, por fim, os mesmos fragmentos diminuídos pelo atrito na peneira, rejeitados os que saem mais duros e lenhosos, como os fios do meio das raízes, torram ao fogo, na panela, como dito acima. Os grãos maiores dessa farinha costumam sair muito parecidos com os grãos de incenso, mas muito amarelos. Quase todos os europeus que vivem na América, assim como os índios, gostam muito dessa farinha e têm-na entre suas delícias. Preferem-na facilmente ao pão de trigo, quando está fresca e ainda não contaminada por nenhuma umidade. Na verdade, não se pode conservá-la por tanto tempo quanto aquela que chamamos acima de cica.

A farinha cica mais torrada ao fogo, e também a que chamamos de farinha d'água, alguns socam no pilão com bastante força, colocando aos poucos, até que se dissolva em grãos miudíssimos, ou, se preferes, num pó de cor quase amarela. A farinha assim obtida, com um caldo quente derramado em cima, tem um ótimo sabor e fornece um alimento muito bom.

Como os índios não usam instrumentos para comer, lançam a farinha com a mão na boca aberta, com admirável destreza, de forma que nenhum grão quase cai ao chão. Quando quis imitá-los, para parecer americano, acredita-me, enchi com mais facilidade e muito mais vezes que a boca, os dois olhos, involuntariamente, sob as gargalhadas dos presentes.

Os americanos extraem também da 'mandioca' outra farinha, que chamarás mais corretamente por esse nome. Preparam as raízes exatamente do mesmo modo que para fazer a farinha d'água. Torram ao fogo, de maneira muito diferente, os fragmentos sobre a panela. No começo, cuidam para que o calor do fogo seja muito mais brando e sempre igual; então, trituram sobre a própria panela os fragmentos, mexendo sempre e vigorosamente, para que não sequem em grãos. Desse modo, fazem com que todos os fragmentos se dissolvam numa farinha de cor branca, finíssima e muito tenra, muito parecida com a nossa farinha de trigo. Dessa farinha, que se chama 'carimã', fazem pães e muitas outras coisas, que, no entanto, embora se conservem por poucos dias, podem ser comidas à vontade pelo homem, enquanto tiver fome.

Venho, agora, distintíssimo Bassi, ao que está escondido nas raízes da mandioca, um finíssimo e muito tenro suco que os índios chamam 'tapioca'. Assim, esse suco das raízes da 'mandioca' é, sem dúvida, a parte principal e muito melhor, sem o qual todas as outras coisas que são feitas daquelas raízes não teriam nenhum sabor e mal poderiam servir de alimento. Desse modo, os índios costumam separar a 'tapioca' das raízes: esfregam e comprimem muitas vezes, com toda força, com as duas mãos juntas, os miudíssimos fragmentos das raízes, recolhendo num recipiente o suco que escorre entre elas, assim, pois, fazem sair o suco com sabor. No espaço de aproximadamente duas horas, deposita-se todo no fundo do vaso o suco ou a 'tapioca', de uma belíssima cor láctea. Nesse vaso, sob água, eliminado antes o líquido nocivo, a 'tapioca' pode ser conservada por muitos dias, dez ou mais, se a cada dia sempre for derramada sobre ela uma água nova.

A 'tapioca', se for bem seca e espremida com os dedos, dissolve-se numa finíssima farinha resplandecente, de uma belíssima candura. Daí provém o amido, a goma e aquele pó, importante ornamento principalmente para as 
cabeças da mulher. Também costumam fazer com essa farinha sucos muito saudáveis, e úteis principalmente, de modo admirável, aos doentes do peito.

A farinha, na verdade, que vulgarmente é conhecida como 'tapioca', e que pode ser conservada por muito tempo, costuma ser feita assim. Sobre uma panela, os índios torram ao fogo a 'tapioca' ainda fresca e mole dissolvida em fragmentos, até que sequem em fragmentos um pouco maiores e grãos de cor branca. Desse modo, os grãos, enquanto quentes, se apalpados com os dedos, sente-se que são moles como se fossem de cera, que, no entanto, passado o calor, tornam-se imediatamente duríssimos. Faz-se amplíssimo uso dessa farinha, mas, principalmente para os que sofrem do peito, costuma trazer muitas vezes uma grande ajuda.

Há uma bebida muito usada feita da 'tapioca' deitada em água fervente, muito célebre e distinta com esse elegantíssimo nome de 'tacacá'. Enfim, pode-se dizer quão avidamente quase todos os brasileiros, assim como os europeus habitantes daquela região, gostam dessa bebida e dela consomem. Mas a 'tapioca' deve ferver na água só um pouco, para que não se transforme em grude; ao mesmo tempo, deve-se mexê-la constantemente para não se transformar em grumos. Em seguida, caldos de outro gênero são misturados com o suco da mandioca já cozido e pimenta esmagada; isto resulta numa bebida muito mais suave. Contudo, todos os que dela consomem pela primeira vez costumam ser levados ao vômito a partir da extrema náusea que origina por causa da força e de certa leveza. Consome-se essa bebida quando ainda morna; alimenta de forma admirável e abranda a fome.

Também da mesma 'tapioca' faz-se um tipo de bolo chamado de beju cica. Os bolos secos desse modo, sobre uma panela com o calor do fogo, consumidos ainda quentes com manteiga espalhada, têm um paladar, sem dúvida, do melhor e mais recompensante sabor.

Os bolos maiores e mais comuns, que os índios chamam beju, costumam ser feitos em grande quantidade dos fragmentos de 'mandioca', com o suco extraído antes, e dos quais é feita a farinha cica. Contudo, os bolos desse modo, uma vez frios, tornam-se quase sem gosto e, ficando aderentes ao céu da boca, tornam-se muito difíceis de engolir.

Desses bolos, mas maiores e mais grossos, os índios produzem uma bebida fortíssima e muito generosa, contudo, de sabor desagradável e austero, que chamam beju, açu, cauim ou, ainda, beju açu, e preparam para eles do seguinte modo. Dispõem os bolos em folhas maiores estendidas, de modo que, postos uns sobre os outros, formem quase um cilindro de pé. Depois de poucos dias, toda a superfície externa desse cilindro começa a embolorar e tinge-se de uma cor rósea com manchas pretas e amarelas de todos os lados. Então os índios separam os bolos agora umedecidos pelo calor e doces ao paladar, e fazem com que cada um, estando mais exposto, se torne igualmente bolorento. Quando veem que isso aconteceu, despedaçam todos os bolos com as mãos, introduzindo-os numa água muito quente. Então, misturam todos com força até que se transformem em pó; separam todo o líquido com uma peneira finíssima, recolhendo-o em vasilhas de barro prontas para isso. Nessas vasilhas, o líquido é fermentado e ferve de seis a oito dias, e algumas vezes recebe tanta força que até rompe os vasos. Esse licor, porém, pode ser conservado de cinco a dez dias, contanto que permaneça completamente intocado e em repouso no vaso. Porque se algo for tomado do vaso, o restante do licor, para que não azede, tem que ser todo tomado em seguida. Isto, com certeza, os índios nunca costumam recusar. Os índios, e principalmente os bárbaros, tomam dessa poção até se embriagarem, enquanto, ao mesmo tempo, celebram juntos os augúrios com as danças mais solenes e com um canto que causa espanto, conforme o costume.

Quase do mesmo modo, porém muito raramente, daquele bolo que acima chamamos beju cica os índios também produzem outra bebida que provoca a embriaguez de forma muito mais rápida e mais forte. Alguns europeus, com a

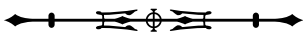


ciência do químico, tornam essas bebidas mais finas e mais suaves, e delas sempre dispõem para várias ocasiões, pois as apreciam muito.

Mas também as folhas da planta da 'Maniva' costumam ser preparadas muitas vezes pelos índios na alimentação, como legumes. Amassam as folhas, seguramente no pilão, e cozinham ao fogo em água, com pedaços de carne ou de peixe, com gordura também adicionada ao caldo de mandioca, pimenta e tempero. Essa comida, que chamam de 'maniçoba', embora pareça ser de bárbaros, eu não pude desprezar. De fato, há oito anos, quando eu percorria as margens do rio Amazonas, aconteceu que, depois de um longo caminho feito em muitos dias, como os soldados amotinados empreendessem a fuga, com enorme medo dos habitantes e com prejuízo, destruíram todas as coisas que pudessem servir para uso dos inimigos. Foi o fato pelo qual, como já faltassem alimentos, nós nos desviamos também da passagem pelas províncias próximas.

Por fim, sobre o suco da 'mandioca', que os índios chamam de 'tucupi' ou 'manicuera', resta alguma coisa a dizer. Esse suco, cor de enxofre, espremido das raízes, cru, costuma ter um sabor doce e agradável; no entanto, contém um veneno muito pernicioso e muito forte. Todos os animais, pois, de qualquer espécie, se beberem desse suco em maior quantidade do que se pode, têm uma morte preparada e pronta. Primeiro, o corpo começa a tremer e a inchar muito, logo se seguem as vertigens; em seguida, o frio nas extremidades dos membros e, por fim, a morte. Sem dúvida, lembro-me de que muitas criancinhas dos índios, escapando dos cuidados da mãe, foram assim mortas, porque tomaram, sem que ninguém visse, o suco cru da mandioca. Os porcos, no entanto, e os veados, e muitos outros animais bem menores, se comerem as raízes ainda com casca, que apreciam muito, não sofrem de nenhum incômodo que antes foi mencionado. Muitíssimos insetos e, principalmente, multidões de inúmeras formigas devastam as plantações de 'maniva' com grande prejuízo para os agricultores, e nem por isso morrem. Entretanto, os homens não podem consumir, sem certíssimo risco de morte, nem o suco, nem o que quer que seja das raízes, enquanto cru, nem as próprias folhas verdes ou não cozidas no fogo.

Muitas vezes, porém, acontece que animais maiores e mais robustos, como, por exemplo, os cavalos, os bois e outros animais desse tipo, escapam por pouco da morte, se tendo bebido somente um pouco do suco venenoso, imediatamente, sem nenhuma demora forem socorridos com algum medicamento. Os índios derramam na boca dos animais que estão com palpitações e claramente prostrados um óleo que leva ao vômito e, ao mesmo tempo, colocam um fogo bem forte ao redor até que todo o corpo do animal se banhe de suor. Entretanto, muitas vezes, os animais morrem apesar de toda presteza e do cuidado tomado.

Embora, por outro lado, o suco da 'mandioca' contenha nele um veneno tão mortífero, se for cozido no fogo, não prejudica de forma alguma e tem um uso enorme. Em quase todos os alimentos, pois, muitos habitantes do Brasil costumam adicionar esse suco que chamam pelo mesmo nome, ou seja, 'tucupi'.

Com esse mesmo suco de 'mandioca' aquecido durante muito tempo, impregnado de uma cor preta, muitos índios, depois de engrossá-lo moderadamente com 'tapioca' para tornar sólido e duro, recobrem o corpo. Isto é o que chamam de tucupi pixuna e guardam para conservar alimentos por muito tempo. É um condimento certamente muito digno dos banquetes dos bárbaros.

E isso, Bassi caríssimo, é o que preparei para escrever-te sobre a planta da 'maniva', ou antes, sobre os principais usos da 'mandioca' entre os povos do Brasil. Eu mesmo vi a maior parte deles, e não só nas cidades vizinhas do Pará, mas também em outros lugares muito distantes daquela cidade observei-os cuidadosamente. Omiti, de propósito, muitas coisas para que, enquanto me esforçava para agradar-te, não te trouxesse aborrecimento. Na verdade, dessas 
coisas que reuni nesse discurso, poderás ver por ti mesmo, facilmente, aquilo que outros escritores que trataram desse assunto disseram menos corretamente. Não quero tocar nesse ponto. Tu, que tens muitos livros, que não dispensaste gasto, nem trabalho, nem diligência, para construir uma biblioteca doméstica, e és aquele que excedes tanto na memória e na experiência das coisas naturais, de forma a não ter falta de nenhum livro sobre todas essas coisas que te escrevi, terás uma opinião. Julgarás que não me faltou crédito para narrar esses fatos que eu mesmo testemunhei. Quanto ao mais, se por acaso cometi algum deslize, ignora-lo-ás e corrigi-lo-ás, pois não vais exigir elegância de um homem já tão perto do americano. O que o irmão e os meus outros, que também são teus, fazem? Como vão? A que se dedicam? O que acontece na nossa Academia? Estou ávido de saber de ti e de Zanotti, Francisco e Eustáquio, dos quais nenhuma distração nunca apagará da minha memória, queiras cumprimentá-los muito em meu nome. Desaparecerei, se não colocar antes de tudo uma conversinha com eles ou contigo, não direi da América, mas de todo orbe terrestre. Passa bem e ama-me, como fazes.

Tradução de Abner Chiquieri.

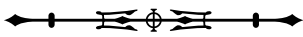




\section{Anexo 5. "Sobre o rio Amazonas".}

Propus-me fazer uma dissertação sobre o maior rio de todo o orbe terrestre, ótimos companheiros e ouvintes aqui presentes, ilustríssimos na erudição e na doutrina, para expor aquilo que eu próprio pude observar muito ampla e cuidadosamente; nas outras coisas, que somente ouvi de outros ou aconteceu-me ler em livros de autores que trataram daquele rio, pouco ou nada tocarei. Com efeito, muitas coisas são ditas por muitos sobre aquele rio, que não são verdadeiras ou que devem fazer parte de lendas; eu não houvera julgado assim facilmente se eu mesmo não tivesse visto todas as coisas nem navegado nas primeiras origens do rio até o oceano; eles, porém, caem no erro mais facilmente e mais frequentemente do que se pode dizer; costumam assumir muitas coisas como certas ou conformes com a verdade, que muito frequentemente são ditas por outros, se não com menos sinceridade, certamente com menos correção, e daí nasce uma discussão sobre coisas, principalmente, dúbias ou obscuras. Portanto, omitirei de propósito muitas coisas, tornando esta minha exposição mais breve e concisa; não são suficientes, no entanto, para esclarecer plenamente o que decidi trazer a público, o que cada um de vós deve perceber sobre esse tão grande rio e aquilo que lhe diz respeito.

Na parte ocidental da América do Sul, existe uma extensíssima e, de longe, celebérrima região peruana. Nela, perto do oceano Pacífico, há uma cadeia muito conspícua de altíssimos montes, que avançam do norte para o sul. Os mais altos cumes desses montes e as encostas são eternamente carregados de neves perpétuas. Ainda que esses montes se elevem quase da parte média da mesma zona tórrida, os vales e os lugares mais baixos se enchem a maior parte do tempo do maior calor; como, contudo, assim se elevam, de modo que alguns sobem quatro milhas e mais acima da superfície do mar, não pode acontecer que nessa tão grande altitude não se enrijeça tudo com o frio e o gelo, e a própria neve que cai frequentemente bastante não cresça numa massa maior e duríssima.

Portanto, se alguém imagina uma superfície no ar como que suspensa e quase paralela ao horizonte, como que indo ao encontro de todos aqueles montes, separando as partes mais altas deles das mais baixas, verá tudo o que está acima daquela superfície carregado de neves e gelos perpétuos; enquanto isso, abaixo da mesma superfície, com um frio já mais ameno, rochedos, terrenos, rochas desarraigadas, terras e plantas, tudo o que existe ver-se-á molhado por inúmeros regatos de águas, pelas neves que escorrem constantemente, pouco a pouco se liquefazendo.

Aqueles regatos que eu disse, por toda parte que vão juntos uns com os outros, aos poucos se fazem maiores e mais fortes. Estes, encontrando-se uns com os outros, transbordando pelas sinuosidades dos montes, transformam-se, então, em torrentes maiores. Deles crescem outros muito maiores que fluem e que são, de novo, as primeiras origens de muitos e grandes rios. Na verdade, outros grandes rios desses correm com grande ímpeto para o vizinho oceano Pacífico; e muitos outros chegam à imensa planície que se estende da região ocidental para a oriental, mais de 1.200 léguas até o oceano Atlântico, descendo geralmente numa correnteza pacífica e suave.

O próprio rio Amazonas, sobre o qual me propus falar, tem essas mesmas origens que disse há pouco e parece ser, com folga, o maior de todos os grandes rios, por direito e por mérito, que na terra da América se lançam com esse enorme volume de águas. Quase todos os outros que nascem ou dos montes peruanos ou talvez de outros, que atravessam num longuíssimo curso grande parte do Brasil, deságuam finalmente no rio Amazonas e aumentam-no com tão grande quantidade de água, que, em certos lugares, não aparenta ter o aspecto e a condição de um rio, mas o de um lago muito amplo, ou mais parece imitar a grandeza e a imagem de um pequeno mar qualquer que ocupa os interiores das terras.

Esses rios afluentes são muitos e muitos são grandes. Entre eles, contudo, enumeram-se alguns mais nobres do que todos os outros, cujos nomes, na verdade, eu diria com prazer se pudessem ser bastante fácil dizer em latim. Um há a que

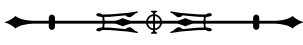


chamam Negro, de tão grande tamanho entre os outros, que poderia disputar de algum modo também com o próprio rio Amazonas. Eu, realmente, quando fui levado pela primeira vez ao rio Negro, para fazer o caminho do povoado de 'Mariuá', que está situado na margem esquerda do rio para os que vão, e dista da foz um caminho de muitos dias, vi tão grande força de águas e tamanha amplitude de leito, que fiquei logo na maior dúvida se claramente estava entrando ou saindo de qual dos dois rios; se não fosse o caso de ter entrado pouco antes no próprio rio Negro, eu mesmo não teria visto coisa completamente admirável e digna de ser conhecida.

As águas do rio Amazonas tornam-se brancas ao máximo por toda parte, naturalmente com um limo finíssimo difuso entre elas e muito solúvel. Por outro lado, no rio Negro, como as águas não contêm limo nenhum ou muito pouco, parecem tingidas de um dourado perpétuo e tomadas de uma cor obscuramente brilhante, ficando admiravelmente negras. Eu acreditaria facilmente que alguns atribuiriam a isto a causa do nome do rio.

E assim, no rio Amazonas, abaixo da foz do rio Negro, as águas descem num espaço de quase meia légua de cada rio, que parecem fluir divididas e completamente afastadas, como se houvesse uma parede interposta e avançando por quase metade da extensão do leito. Da parte esquerda do rio, para os que fazem o caminho abaixo, por onde naturalmente se entra no nosso mesmo rio Negro, veem-se as águas totalmente tornando-se negras, enquanto, ao mesmo tempo, da parte direita aparecem completamente alvejantes. É, com certeza, um lindo espetáculo e para olhar sem parar, e não é fácil de ver senão nesse tão grande rio!

Depois de perfazerem quase meia légua, como disse, as águas dos dois rios, separadas e desse modo divididas, começam a misturar-se. Daí acontece que aquele negro da parte esquerda do rio diminui. E diminui cada vez mais, enquanto as águas daí provenientes misturam-se sempre mais, até que desaparecem totalmente, quando as águas estiverem completamente misturadas. Então, em toda superfície extensa em que a correnteza aparece, as águas se mostram alvacentas, como antes.

Quem ainda não acredita que o rio Negro também possa ser contado entre os grandes e nobres rios de todo o orbe terrestre, quando carrega tamanha abundância de águas e se sobressai com tão grande força, a ponto de conseguir, de certa maneira, repelir e quebrar, ainda que por pouco tempo, até as maiores forças do próprio rio Amazonas? Quem ainda não vê que é preciso que o próprio Amazonas seja muito maior e mais importante que o outro, cujos esforços, todos em vão, por fim, se acabam e as forças opostas são vencidas pelas forças do outro e, finalmente, se esgotam totalmente?

Mas, agora, retorno às origens do rio Amazonas. Estas, sem dúvida, são tantas e tão diferentes, que é muito difícil alguém poder definir qual de todas é a origem primeira desse tão grande rio, e qual a principal delas. La Condamine, embora hesitando, pensa ser a ucaialiana. Por que La Condamine teria duvidado é demorado dizer e, além disso, inútil. Apesar disso, teria declarado ideias que mostram que o mesmo rio chamado Ucaiali é muito menor que o rio Amazonas; se ele quisesse, poderia ter duvidado menos. Poderia, pois, um pouco mais livremente, ter sido fixado por ele que entrar no rio Ucaiali é entrar no nosso [Amazonas] e, ao mesmo tempo, que é ele a sua origem principal.

Uma vez dado o encontro desses dois rios, diz que encontrou tamanha profundidade que não poderia alcançar o fundo do rio baixando a âncora até 80 côvados. Assim, seguramente, terá sido. Mas, visto que La Condamine quase sempre diz isso quando trata da profundidade da água, receio muito que, muitas vezes, caindo no erro mesmo sem querer, haja algum lapso. Ainda que tenha feito aquele seu caminho com águas correndo na maior profundidade, não vejo realmente que só a profundidade da água pudesse fazer com que não conseguisse, tantas vezes, atingir o fundo do rio.

Decididamente, e com facilidade, ninguém compreende que esse nosso rio, como quase todos os outros, quando ainda está impetuoso, ou quando ainda avança por lugares abruptos de montanhas com grande força e se precipita entre as paredes e os enormes rochedos, caindo com horrendo fragor, inúmeras vezes, das cachoeiras, é assim preparado pela

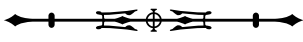


natureza de forma a não poder sujeitar-se de nenhum modo a interesse algum dos viajantes. Ninguém, pois, a não ser que prefira morrer, empreenderá fazer espontaneamente e com segurança um caminho para outro lugar entre aqueles lugares abruptos sem ser pelas suas águas. Existem, porém, alguns habitantes dessas regiões que, com uma audácia quase incrível, percorrem assim as regiões do rio extremamente temíveis e, conduzidos até em barcas ou colocando-se em alguma construção de poucos paus, não temem precipitar-se das alturas das cataratas para as partes mais baixas do rio.

Volto agora para o rio, trazido por fim à imensa planície que mencionei, e deslizando já numa correnteza plácida em direção ao oceano. Não encontrarás, agora, nenhuma cachoeira nesse tão longo percurso do rio que traga o medo, nenhuma rocha, nenhum rochedo adiante que possa provocar-te a ruína; e, a menos que sobrevenham tempestades, como frequentemente costuma acontecer, que perturbam o rio, farás o caminho muito agradável e tranquilo, com o vento e com os remos. As barcas, contudo, com as quais é preciso navegar próximo às margens do rio, muitas vezes se chocam com troncos de árvores caídos das florestas maiores próximas, que, ficando sob a água, têm a capacidade de trazer embaraços. Mas, os condutores de botes que querem ser um pouco mais diligentes podem precaver-se facilmente desse perigo, mesmo à noite. Talvez sejam mais temíveis os turbilhões que, em alguns lugares, nascem ora de uma súbita curva das margens, ora de alguma ilha existente nas proximidades. As barcas, pois, ao chegarem mais perto, facilmente são arrebatadas por esses turbilhões, dos quais, depois, muito penosamente e a não ser com grande esforço dos remadores, podem sair. Os moradores, no entanto, que reconhecem muito bem todos os lugares em que a água costuma ser impelida e se revolver com esses movimentos, esquivam-se de toda a perniciosidade dos turbilhões, impelindo os barcos para outro lugar sem nenhuma dificuldade.

Na verdade, nessa planície com uma correnteza tão suave e calma, dificilmente é possível afastar da linha horizontal o fundo do rio que deflui. Com efeito, as barcas, o ano inteirinho, se não houver vento, sobem só com os remos contra a massa de água corrente, embora devam fazer o caminho com um pouco mais de dificuldade que aquelas que navegam mais longe das margens ou depois que as águas chegaram à maior profundidade que podem ter. Além disso, inúmeras ilhas, emergindo das águas em quase todas as partes, das quais aquelas, na verdade, que não existem mais perto das origens do rio, distam quase 1.200 léguas do oceano, e muito mais que isso, se estou calculando corretamente, parecem mostrar-se. Eu, na verdade, estimo convir inteiramente que o limite último do rio, do lugar que os brasileiros chamam de 'Pauxis' [Óbidos] até o oceano, estende-se num espaço de 200 léguas e mais. Portanto, o fluxo do mar chega até aquele lugar que mencionei, e se observa sempre em horas fixas do dia. Embora, pois, a profundidade da água apareça um pouco só aumentada naquele lugar, aumenta, contudo, e aumenta não somente pelo fluxo do mar.

Como as ilhas são tantas, que quem tentar deduzir o número delas enfrentará uma grande dificuldade, são muito diferentes também quanto ao formato e ao tamanho. Existem, então, as quase redondas; as que têm forma de triângulo ou de quadrilátero; e as que, por serem demasiado longas, parecem quase carecer de largura. Muitas, por outro lado, são oblongas e agudas na ponta. Existem também as pequenas, as médias e as grandes; existem, por fim, as maiores. Eu vi muitas que, como eram muito mais largas que as outras, atingem só no comprimento a quarta parte e mais de uma légua. De todas, porém, surgem selvas e se mostram distintas com tão grande variedade de plantas e de árvores que, sozinhas, essas ilhas contidas nesse tão grande rio poderiam alimentar uma abundância absolutamente incrível de animais.

Em que amplitude, porém, deve estender-se esse maior rio, não é difícil que alguém possa calcular se retiver na memória o que acabo de dizer sobre o enorme número de ilhas. E, sem dúvida, nesses lugares onde as ilhas ocorrem com mais frequência, a largura do rio é tanta que dificilmente se encerra num espaço de duas ou três léguas. Na verdade, nesses lugares, principalmente quando as águas estão muito altas, fluem com uma abundância muito maior, assim a largura do rio cresce e aumenta tanto que se somares uma quarta légua, terás dito pouco. Geralmente,

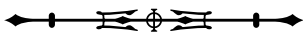


porém, conclui-se por um espaço de uma légua. Assim, abaixo das embocaduras do rio Negro e de outro afluente (esse afluente é chamado 'Madeira' pelos portugueses), essa medida de largura permanece quase a mesma por um trajeto do rio bastante longo. Mas, subindo o rio para o lugar que chamamos de 'Pauxis' [Óbidos], diminui tanto que, nesse lugar, não chega a mais do que 95 seis-pés parisienses. La Condamine afirma que essa medida da largura do rio naquela seção foi por ele definida geometricamente.

Sobre as várias alturas da água que são observadas no espaço de um ano nesse tão grande rio, direi pouca coisa. Queria que fossem conhecidas, contudo, as coisas sobre as quais falarei, somente das partes superiores do rio, que ficam mais longe do mar, não das partes inferiores, que ficam menos distantes do mesmo mar. Naquelas [as partes superiores do rio], pois, ele [o mar] tem muito pouca importância ou, quem sabe, até absolutamente nenhuma. As chuvas, sem dúvida, que na mais alta região peruana caem mais frequentes em certos períodos do ano, como costumam durar por um espaço de muitos dias, como as águas dos rios podem conquistar por elas mesmas uma grande força nas origens, fazem com que as neves, que dissemos existir perpetuamente naqueles montes altíssimos, derretam mais rapidamente. Certo calor que, por acaso, acompanha geralmente as chuvas derrete, assim, as neves mais rapidamente e mais impetuosamente. Portanto, não é absolutamente de admirar que todos os rios originados naqueles montes ganhem em certos meses do ano tanta força nas águas, que as próprias águas, que conseguem uma altitude quase incrível, vencidas e ultrapassadas as margens altíssimas, por fim se espalhem nas florestas próximas.

Desse modo, principalmente nos meses de junho e julho, as águas do rio Amazonas chegam à maior altura que podem atingir. Essa, após os meses que seguem, decresce e diminui gradualmente, de forma que, quase no fim do ano, encontra a menor de todas. Dificilmente pode-se acreditar ou dizer que intervalo existe entre essa mínima e aquela máxima altura das águas. Eu, sem dúvida, que pude ver muitas vezes e observar cada situação do rio, uma vez que devia fazer as viagens naturalmente maiores em diversos períodos do ano, não pude ver muito, a partir daí, muito grande diferença das alturas das águas nesse rio. Alguém poderia reconhecer sozinho, sem dúvida, facilmente essa diferença, se tivesse navegado no rio enquanto as águas corriam tão baixas. Então, verá mostrar-se uma espécie de vestígio de inundação anterior nas margens altíssimas por meio dos troncos de árvores consistentes, ajustado numa linha quase horizontal. E não achará difícil que esse vestígio se eleve 50 pés e algumas vezes mais acima da superfície da água corrente. Se isto, sem dúvida, assim acontece, quanta altura haverá precisamente na mais alta inundação do rio, com águas correndo moderadamente, abundante em todo caso na metade do rio, e onde ocorre?

Enfim, o curso desse rio tão grande dirige-se de tal forma para o meio da zona tórrida que, começando a quase 11 graus de latitude sul, chegue ininterruptamente ao Equador, até que termine, finalmente, sob o próprio Equador, no oceano Atlântico. Na foz, o rio, precipitando-se para o oceano, revela-se com tamanha amplitude que alguns geógrafos não hesitaram em atribuir como sua medida 80 léguas ou mais. No entanto, La Condamine acha que corrigiu esse erro de vários geógrafos, estimando em dois graus e meio, ou 50 léguas, o espaço que a amplitude da foz tem, incluindo o intervalo entre o Norte e as ilhas chamadas de 'Joanes' [arquipélago do Marajó], que ficam entre promontórios.

Tempestades, algumas vezes, são provocadas, muito furiosas, ora no próprio rio Amazonas, ora nos outros afluentes, especialmente os maiores. Na verdade, parecem-me as mais perniciosas de todas e dotadas das maiores forças aquelas provocadas pelo vento que sopra vigorosamente da região quase ocidental em certos e determinados períodos do ano e que são trazidas com grande ímpeto numa certa e determinada região do Brasil. Esse vento costuma durar três ou quatro dias e desencadear-se com extrema nocividade. Então, todas as florestas por onde o vento irrompe são sacudidas com muita força, e muitas árvores, até as mais robustas, são derrubadas, e muitos animais morrem; nos rios e nos lagos

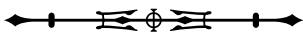


também; as águas são erguidas por toda parte em ondas tão grandes que uma grande e incrível abundância de peixe, inclusive dos maiores, morre, tendo seus corpos, ao mesmo tempo, lançados enfraquecidos nas areias. Não há, então, nenhuma segurança para se navegar com barcas; os que se entregarem com tanta ousadia à violência da tempestade, a eles, antes de mais nada, está reservado o naufrágio, ou mesmo a morte. Essas tempestades, contudo, que são muito raras e acontecem uma ou duas vezes ao ano, chegam temíveis geralmente sem chuva e sem nenhum estrondo do céu.

São de longe mais frequentes as que atormentam todo o Brasil, as quais, embora se excetuem poucos meses, costumam abalar-se com grande força sobre aqueles lugares durante o espaço de seis a oito dias, para, às vezes, voltarem poucos dias depois. Com elas, geralmente, um vento violento se desencadeia e caem grandes chuvas, sem granizo; porém, com o céu, enquanto isso, resplandecente e trovoando horrivelmente.

Quando, pela primeira vez, entrei no rio Amazonas, de repente sobreveio uma grande tempestade, quando o sol declinava no ocaso, trazendo a todos que comigo estavam grande medo e lançando-nos em grande perigo. Vinte ou mais barcas que navegavam juntas, das quais algumas eram maiores e capazes de suportar as ondas do mar, foram levadas para a margem mais próxima do rio; pouco faltou para que todos fôssemos aniquilados pelas ondas que se precipitaram. Todos, porém, livraram-se do naufrágio com a arte e a força dos remadores americanos, que, colocando-se nus na areia, com os corpos imersos pela metade na água, os esporões dos navios voltados contra as ondas, evitaram o tempo todo o ímpeto delas e a maior violência com grandes esforços e, em suma, com incrível paciência. Enquanto isso, caía uma enorme chuva e, quase no meio das trevas, a noite já avançando, muitos trovões e relâmpagos aterrorizavam mais, quando, por fim, entre as mesmas barcas, um gigantesco raio caiu com tão grande estrondo e tanta força de luz, que não se podia, durante meio quarto de hora ou mais, ver o que tocava nos corpos nem ouvir o que os outros diziam. Então, todos se ajudaram e todos foram salvos. Pouco depois, a noite já escura, a tempestade dissipou-se; e nós, finalmente com tudo em paz, levamos as barcas para o melhor porto, dando graças ao Deus maior e ótimo, que nos tinha tirado de tão grande perigo. Porque, se aquele raio tivesse caído sobre a pólvora que era transportada em grande quantidade numa daquelas barcas, dificilmente alguém teria escapado entre tão grande número de mortais; nem eu poderia agora estar dizendo a vocês tudo isso sobre essa cruel tempestade. As tempestades deste modo, como costumam abater-se com tanta frequência naqueles rios, é preciso tomar muito cuidado, para que, a noite se aproximando principalmente, seja encontrado para as barcas um porto seguro oportuno e livre de toda violência das águas. Se os nossos condutores tivessem feito assim, e não perdessem tempo perseguindo e molestando jacarés que encontraram presos num lago vizinho, talvez tivéssemos escapado dessa tempestade, ou pelo menos não teríamos sido submetidos à sua tão grande fúria e crueldade.

Existem tantas espécies de peixes vivendo no rio Amazonas e nos rios próximos que a sua variedade pode agradar ao máximo principalmente aqueles que se dedicam à contemplação das coisas naturais. Desses peixes, alguns são enormes e dotados de grandes forças, e parecem ter sido mais destinados pela natureza às ondas do mar do que às águas dos rios. O maior de todos é aquele que os portugueses chamam de 'peixe-boi'a; tem a cabeça muito parecida com a cabeça do boi, se excluirmos as orelhas e os chifres. Alimenta-se das ervas que brotam da água perto das margens dos rios, de tal forma que também isso pode parecer semelhante ao boi. Deve ser colocado completamente no gênero dos cetáceos. A fêmea pare os filhotes e alimenta-os com leite. Os machos, enquanto perseguem as fêmeas, tornamse furiosos e lutam entre si muitas vezes, até que o mais valente e o que mostra as maiores forças consegue a fêmea.

a [Nota dos editores: duas espécies estão presentes no Brasil: Trichechus inunguis (Natterer, 1833), da bacia do rio Amazonas, e Trichechus manatus (Linnaeus, 1758), das Antilhas, costa da Venezuela, bacia do rio Orinoco, Guianas até o litoral do Pará e daí para o sul (antigamente, até pelo menos o Espírito Santo). São mamíferos da ordem Sirenia, família Trichechidae].

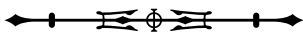


Por outro lado, entre os menores peixes, é preciso, sem dúvida, enumerar o 'torpedo'a, peixe pequeno, na verdade, mas muito temível. De fato, se um homem, nadando, for tocado por um torpedo que, por acaso, esteja passando perto, correrá o maior perigo, pois a parte que for tocada é afetada por uma desagradabilíssima insensibilidade por muito tempo. Tanto isso acontece que um homem completamente submerso na água, já lhe faltando as forças, se ninguém lhe prestar socorro, terá morte iminente e certíssima. Fiquei sabendo de um menino tocado por um torpedo; como ninguém ajudou, morreu enquanto eu ia para lá. Eu mesmo toquei num torpedo ainda vivo preso num vaso cheio de água, não com a mão, é claro, mas com um pauzinho que eu carregava. Mal posso dizer quanto torpor sentiu meu braço afetado e quanta sensação de dor me afligiu. Sei que em muitos livros os autores fazem menção das espécies de torpedos. Esta, no entanto, que vi e toquei, era de cor quase negra e sem nenhuma mancha visível.

Já que o assunto é peixe, falarei também do gênero das raias, assim como tratarei brevemente das que eu mesmo vi. Existem muitas espécies de raias e, geralmente, umas são inofensivas, mas outras poderiam trazer algum perigo. Esses animais ficam, muitas vezes, entorpecidos e quase imóveis na areia, debaixo d'água, na foz dos rios. As que têm a cauda armada com ferrões, se forem esfregadas pelos pés dos que entram nos rios, batem a cauda com muita força e ferem muito cruelmente. Imediatamente vem uma dor tão aguda que aquele que sofrer um ferimento pela raia não duvide que irá se submeter por muito tempo a uma tortura muito atroz. Eu tive um acompanhante ferroado por uma raia. Lamentava-se o infeliz com uma voz horrível, era tanta a sensação de dor com a qual se torturava, que parecia estar completamente louco. Para muitos que estão sofrendo, uma chama acesa de enxofre fervente, umas gotas colocadas no ferimento, com extrema paciência, aquela dor tão grande pouco depois enfraquece, até que, por fim, extinta, o acompanhante estará são e salvo do ferimento sofrido no outro dia. Não aconteceu o mesmo com um religioso da Ordem Franciscana. Ele tinha sofrido um ferimento muito cruel de uma raia. Como não pôde, de jeito nenhum, usar as gotas ardentes de enxofre, poucos dias depois sobreveio a gangrena e, enfim, infelizmente, foi obrigado a ir-se embora da vida. Depois desse caso, afastando-me com horror de todo gênero de raias nocivas, nunca mais pude ir aos rios e entrar para lavar o corpo.

Com tantos peixes e tanta variedade de espécies vivendo naqueles diferentes rios, é fácil que alguém, por conta própria, possa verificar ser necessário que haja muitas espécies de aves aquáticas que persigam os peixes menores e os devorem. De tantas que voam perto desses rios, uma é a mais bonita, sobressaindo-se entre todas as outras com uma cor vermelha elegantíssima. Ouço dizer que é chamada por Lineu Numenium indicumb . Pelos brasileiros é chamada 'Colhereira'.

Antes de falar sobre tartaruga e o jacaré, convém fazer referência à natureza e à índole, para mim admiráveis, de um inseto [sic] que vive principalmente no rio Amazonas. Os brasileiros chamam esse inseto [sic] 'Candiru'c. Tem o aspecto, mais ou menos, de um verme pequeno. Se for esfregado com o dedo, em certo sentido, é liso e dócil ao tato; do outro, mostra-se tão áspero que, com essa aspereza excessiva, pode-se ferir o dedo. Alimenta-se avidamente do sangue dos animais feridos, de modo que até o jacaré corre maior risco se verter sangue de um ferimento sob a água. Em alguns lugares, ocorre quase uma infinita abundância desses animaizinhos. Procura o pênis humano e, se puder, entra muito prazerosamente. Daí porque os homens nunca ousam entrar nos rios dessa região, senão com os órgãos previamente

a [Nota dos editores: Brunelli refere-se ao poraquê, Electrophorus electricus (Linnaeus, 1758), peixe gimnotiforme da família Electrophoridae].

b [Nota dos editores: Brunelli errou em aplicar o nome de 'colhereiro' a esta ave. Trata-se, na realidade, do guará, Eudocimus ruber (Linnaeus, 1758), ave ciconiiforme da família Threskiornithidae. Numenius indicus foi o nome dado a essa ave por Clusius, em seu "Exoticorum" (1605, p. 366), e citado por Linnaeus na sinonímia de Scolopax rubra, na 10a. edição do "Systema Naturae" (Linnaeus, 1758, p. 145)].

c [Nota dos editores: designação comum a várias espécies de peixes siluriformes das famílias Cetopsidae e Trichomycteridae. Essa é a primeira menção ao célebre peixinho na história da zoologia brasileira. Sobre o candiru, consultar Spotte (2002)].

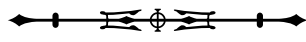


enfaixados e muito bem comprimidos. Porque se esse inseto [sic] entrar naquela parte um pouco mais profundamente, sem dúvida acontecerá que de nenhum modo ele poderá ser expelido ou extraído daí, a não ser por um corte de quase toda a parte; alguns me contaram que isso também aconteceu uma vez enquanto eu fazia o caminho no rio Negro.

Passo às tartarugas, das quais pude observar duas espécies que habitam principalmente aqueles rios. As que pertencem a uma espécie são muito raras, e se excetuares a carapaça, quase nenhum uso têm, certamente porque, como ouvi de alguns, os que comem a sua carne imediatamente são tomados por febres. Se isso, entretanto, acontece realmente assim como dizem, eu dificilmente afirmaria.

$\mathrm{Na}$ verdade, as que pertencem à outra espécie ${ }^{a}$ são tantas e ocorrem sempre em todas as partes, que são suficientes durante quase todo ano para alimentar abundantemente todos os povos do Brasil. Os brasileiros, com efeito, quando a necessidade preme ou existe a ocasião, pegam e trazem dos rios e dos lagos quantas tartarugas quiserem, usando, geralmente, sem dúvida, ganchos de ferro. Nos dois ou três últimos meses do ano, em lugares espaçosos e abertos, pegam tão grande abundância desses animais que vagam juntos e, num curto intervalo de tempo, depois de pegar o máximo, enchem e sobrecarregam muitos botes.

Quando, nesses meses, as águas de todos esses rios, que são poucas e correm numa profundidade bem menor, assim se afastam tanto das margens que as areias que aí se acumulam em grande quantidade aparecem amplamente; quase todas as tartarugas fêmeas, saindo das águas por todas as partes, buscam essas areias para pôr os ovos. Então, vês escurecerem-se enormes trechos de areia de modo admirável, que se prolongam por um espaço de muitas léguas.

Os pescadores, observando isso e, ao mesmo tempo, lançando-se das barcas onde permaneciam, mal se pode dizer que os mesmos, no menor tempo possível, pegam, da forma mais fácil, aquela enorme quantidade desses animais, como disse. Portanto, tratam imediatamente e com a maior rapidez possível de colocar as tartarugas com a barriga para cima, para que não escapem. Muitas, no entanto, fogem, na verdade, as que estão mais perto da água e que ainda não puseram os ovos; deixando as areias, lançam-se o mais rápido que podem, imediatamente, ao rio e fogem nadando. $\mathrm{Na}$ verdade, as que são surpeendidas pondo os ovos, embora tocadas com as mãos e vigorosamente apalpadas, permanecem quase imóveis e olham muito estupefatas os homens. São pegas, finalmente, elas e os ovos que tiverem posto. Então, os pescadores levam para outro lugar as tartarugas que pegaram, depois de encherem completamente os botes, guardam-nas em viveiros e preservam-nas por muito tempo.

Quando as tartarugas põem os ovos, guardam-nos em buracos que fazem na areia, mexendo e jogando a areia principalmente com as patas posteriores, numa velocidade admirável. Há tartarugas que põem, ao mesmo tempo, oitenta ou cem ovos e mais, todos os anos. Na verdade, elas são de um tamanho tão grande e são tão pesadas que muito dificilmente podem ser carregadas cada uma por um homem. Muitas, contudo, porque são menores, põem somente 50 ou 60 ovos. Após botarem, juntam areia e aparam-na com a barriga, para que não se possa assim descobrir facilmente onde se escondem os ovos. Os habitantes, porém, batendo os pés, descobrem geralmente os lugares que contêm os ovos. Desse modo, acumulam uma quantidade quase incrível de ovos, dos quais, como dizem os portugueses, extraem a 'manteiga'. Quase todas as nações brasileiras servem-se dela para temperar os alimentos. Também a colocam como óleo nas lamparinas.

Restam, finalmente, os jacarés, sobre os quais resolvi falar, animais muitíssimo ferozes, sem dúvida, naqueles rios. Também deles duas espécies são enumeradas. Uns são muito pequenos e vistos com uma cor quase verde. Os

\footnotetext{
a [Nota dos editores: a outra espécie é a 'tartaruga-do-amazonas', Podocnemis expansa (Schweigger, 1812), réptil quelônio da família Podocnemidae].
}

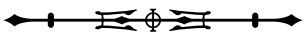


brasileiros bárbaros, como os consideram deliciosos, alimentam-se das carnes deles. Como eu queria experimentar essas delícias, tentei comer um pedacinho de carne de um. Mas, impressionado pelo seu cheiro forte e chocado com a novidade do sabor, percebi em quanto se distanciam o nosso paladar e o dos bárbaros.

Existem outros jacarés muito maiores que esses, que podem pertencer a uma outra espéciea . São quase negros e completamente horrorosos. Como têm muita força, detêm igualmente notável habilidade. Comem os peixes, todos os animais, e até os próprios homens, se os encontrarem nadando nas águas. Com efeito, absolutamente nenhum animal desliza tão veloz nas águas, ou é dotado de tão grande força que possa afugentar um jacaré que ataque ou ouse resistir ao seu furor.

Embora a onça algumas vezes pegue o jacaré e o mate, isto o faz mais por certa astúcia sua que como demonstração de força. Porque, quando pode, foge nadando nas águas, se o jacaré a perseguir. Por outro lado, se o encontrar dormindo ou descuidado nas margens abertas dos rios, com muita velocidade cai sobre ele, que não espera nada parecido, buscando com as unhas os olhos e, imediatamente, dilacera-os e arranca-os e aperta e comprime com tanta força colocada sobre as costas do animal, que ele, já fora de si e lançando-se com a maior velocidade que pode ao rio, de nenhum modo consegue escapar, até que, por causa dos muitos ferimentos infligidos, o ferocíssimo animal morra, por fim, de uma abundante e duradoura hemorragia. Então a onça arrasta para a floresta próxima o corpo do jacaré morto e, despedaçando-lhe os membros, alimenta-se feliz com as carnes do inimigo funesto.

O rio Amazonas, principalmente, alimenta tamanha abundância de jacarés que, para onde quer que os botes se dirijam e avancem naquele rio, os têm ao seu encontro ou perseguindo-os pelas costas. Os jacarés lutam entre si e se disputam frequentemente, combatendo geralmente com as caudas com muita força e grande ímpeto. Tive um de apenas meio pé de comprimento, que, no entanto, esperto para morder, eu não podia de jeito nenhum segurar com as mãos. Como saem tão pequenos dos ovos, é admirável dizer como crescem. Existem alguns que alcançam um comprimento de 10 ou 12 dos nossos pés e mais. Aos que calculam em até trinta pés o tamanho dos jacarés, peço que examinem a que pés querem referir-se.

Quando os jacarés perseguem, nadando nas águas, excedem em muito a rapidez de quase todos os outros animais, mas, postos em terra, não conseguem correndo alcançar de modo algum um homem. Vi alguns americanos que me ajudavam nos remos maltratar com umas estacas bem longas um jacaré que encontraram dormindo na areia. Nenhum dano, porém, sofreram do jacaré despertado e agora já os perseguindo. Quantos havia, embora fugindo, subiram salvos e incólumes de novo para a barca; o jacaré, porém, como os remadores já tinham escapado e nada mais pudesse, mordendo as estacas, lançou-se, por fim, com grande ímpeto, furioso, na água.

Esses animais emitem, algumas vezes, vozes terríveis demais, que suscitam medo, se ouvidas inesperadamente. Ouvi-as muitas vezes de noite, nunca durante o dia. Não poderia dizer facilmente se fazem isso por alguma sensação de dor, como pensam os habitantes, ou impelidos por alguma outra necessidade. Pensarias num mugido de touros ou num rugido de leões a ressoar em torno de todas as florestas. Finalmente, para terminar de falar sobre os jacarés, as fêmeas desses animais, assim como as tartarugas, guardam os ovos nas areias ou até na lama. Na lama, pois, são muitas vezes encontrados, como vi, e daí são levados prazerosamente pelos bárbaros brasileiros, que, como comem quase de tudo, se deliciam admiravelmente com os ovos de jacarés.

Finalmente, por que não trazer a público o que penso, nesse espaço derradeiro, sobre o nome do rio? O espanhol Francisco de Orellana foi o primeiro de todos que, entrando pelo rio, navegou até o oceano Altântico e, talvez assim

\footnotetext{
[Nota dos editores: nessa passagem, Brunelli trata do jacaré-açu, Melanosuchus niger (Spix, 1825), réptil crocodiliano da família Alligatoridae].
}

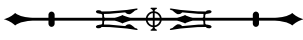


como homens, viu muitas mulheres vagando em ambas as margens do rio e caçando com arcos e flechas aves e outros animais. Penso que esse costume, bastante conhecido por todos, existe até os nossos tempos junto a algumas nações bárbaras do Brasil. Como, geralmente, os homens são dados, mais do que é preciso, ao sono e ao ócio, as mulheres, muitas e muitas vezes, entram nas florestas para buscar alimento, onde pegam aves e muitos animais que aí ocorrem em grande quantidade. Nelas, quase sempre usam flechas para pegar e golpear, lançadas de um forte e sólido arco. Fazem também o mesmo para matar os peixes, principalmente os maiores. Tanto as mulheres como os homens dessas nações são excelentes e temíveis nessa arte.

Então, por que não pensarmos que tenha vindo à mente daquele espanhol e dos colegas que o acompanhavam, ao ver e considerar essas mulheres selvagens, quase nuas, mas armadas, aparecendo sem cessar nas selvas, aquelas antigas e muito célebres amazonas, que, outrora, como narra a história, ou a ficção conta, sabemos que usavam armas e faziam muitas guerras, e na ausência de qualquer guerra, usassem, geralmente, o tempo e as forças para caçar e matar feras? Acredito que se tenha relacionado com essa única, embora pequena e tênue, semelhança com essas mulheres para que esse enorme rio também tenha recebido o nome das Amazonas, que, posteriormente, assim tenha sido guardado constantemente até nossos tempos como mais eficaz e mais nobre que os outros. Orellana, Maranhão, Solimões, por cujo nome os portugueses costumam chamar uma parte superior do rio, são termos completamente obscuros ou que, certamente, são muito pouco lembrados pelos autores.

Quando, pois, Francisco de Orellana caiu sobre as americanas, no Amazonas, e testemunha tê-las visto, se quer dizer as mulheres a que pouco antes me referi, concordo de boa vontade. Se, porém, pensa numa república formada por essas mesmas mulheres que viu e por outras inúmeras que não viu, que são essas mesmas mulheres que recusavam qualquer união com homens, como se conta daquelas Amazonas asiáticas, que pretende que todas se deleitavam com o estrépito das armas, a única glória das guerras, está dizendo algo ridículo e nada aceitável. Alguma homenagem também deve ser prestada àquele espanhol, que, antes de todos, viu esse espetáculo novo e que, talvez, iludido por alguns habitantes mentirosos daquelas regiões, tenha caído nesse erro por excessiva credulidade.

$\mathrm{Na}$ verdade, o douto e erudito La Condamine, embora não reconheça existir em nossos tempos nenhuma Amazona brasileira, parece aceitar, contudo, a opinião dos que acreditam que outrora existiram ou que pudesse haver alguma república delas. Conta-se um grande número, sem dúvida, de testemunhas sobre cuja autoridade isso se estabeleça. Mas, como afirma que essas mesmas testemunhas são falsas e crédulas e se confesse tocado e impressionado por uma espécie de coisa milagrosa, quem, certamente, pergunto, não se surpreende? E quem não se rirá desse novo e inédito método de provar de um francês? Eu mesmo, que precisei passar a vida durante oito anos nesses mesmos lugares, ou estar presente por intervalos, onde poucos anos antes La Condamine tinha ouvido falar tanto das Amazonas, quando muitas vezes cuidadosamente procurei saber sobre o assunto, nunca encontrei ninguém que entendesse o que eu dizia. Fiquei sabendo que, além desse nome do rio, nenhum outro era conhecido e aceito por aqueles homens, que parecia, na verdade, poder referir-se de algum modo às Amazonas.

Contudo, já chego ao fim do que dizia, ótimos colegas, que aumentais com autoridade esse nosso conhecimento e [me] honrais com a presença, ilustríssimos ouvintes, para que não pareça abusar demais imoderadamente de vossa benignidade e paciência absolutamente singular. O que, pois, expus até aqui, embora dito talvez moderada e sutilmente, ou até inabilmente, mostra bastante, se não me engano, e até mais, o quanto esse nosso rio é importante e ultrapassa todos os outros que correm e se desenvolvem em todo o orbe terrestre, de forma que não se possa encontrar nenhum outro que, com esse, de alguma maneira, seja comparável. Tenhamos, pois, isso como certo e garantido, o rio sobre

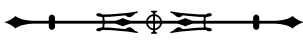


o qual falei, o Amazonas, dos muitos grandes rios que recebe, em abundância e comprimento do percurso, com o qual atravessa quase toda a América do Sul, por onde se estende amplamente, com um imenso volume de águas, que despeja no oceano por uma foz amplíssima, com a multidão de ilhas de tamanho, sem dúvida, não desprezível, que abraça, e, finalmente, com a abundância e variedade de peixes que alimenta, quase infinita, de todos os rios que vemos neste nosso mundo, é de longe o maior e de longe o mais nobre.

Tradução de Abner Chiquieri.

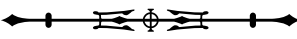

